\title{
DETERMINANTS OF VERTICAL AND HORIZONTAL EXPORT DIVERSIFICATION: EVIDENCES FROM SUB-SAHARAN AFRICA AND EAST ASIA ${ }^{1}$
}

\author{
Aye Mengistu Alemu²
}

\begin{abstract}
This paper analyzes the main determinants of vertical and horizontal export diversification based on a balanced panel data for 41 countries from SSA and East Asia over the period 1975-2004; using FGLS estimation methods with corrected heteroskedasticity and autocorrelation. The results reveal that education, health, and income per capita, population size, infrastructural development and openness are crucial factors to induce vertical as well as horizontal export diversification. FDI was found to be a key factor to speed-up vertical and horizontal export diversification in East Asia, but only for vertical diversification in SSA. The elasticity's of human capital and FDI were much higher in East Asia than SSA. The intuition is that East Asian countries have devoted significant amount of investment on education, health, infrastructure and these in turn created a better conducive atmosphere for FDI inflow. The study also reveals domestic investment plays an important role to enhance vertical as well as horizontal export diversification for East Asia, while it only induces horizontal diversification for SSA. While 'arable land' resource has a positive and significant effect on vertical and horizontal diversification, 'oil' wealth was found to be negatively associated with export diversification. This implies that not all types of natural resource endowment have a 'Dutch disease' effect. While inflation, exchange rate, and foreign aid variables have a mixed effect on vertical and horizontal export diversification, political instability however has a strong adverse effect on export diversification; especially for SSA. The key lesson from East Asia to SSA is that investment on human capital and physical infrastructure through foreign investment as well as domestic capital formation are key ingredients, as are stable macro-economic and political environment, a stable and flexible exchange rate, and a fair and an open trading framework in order to accelerate vertical and horizontal export diversification and ultimately promote structural change on the economy. In line with this, SSA countries should follow a dual strategy of vertical and horizontal export diversification, mainly by supporting backward and forward linkages into higher value-added resource-based industries and gradually shift production and exports from customary products to more dynamic ones by developing competitive advantage in the world market.
\end{abstract}

Keywords: Domestic Capital; Human Capital; FDI; Infrastructure; Inflation; Exchange Rate; Natural Resource Endowment; Foreign Aid; Vertical/Horizontal Export Diversification; Sub-Saharan Africa; East Asia

\footnotetext{
${ }^{1}$ The final version of this article was submitted in April 2009.

${ }^{2}$ PhD Candidate, Graduate School of Asia Pacific Studies, Ritsumeikan Asia Pacific University, Beppu-shi, Oita-ken, Japan

Postal Address: Kannawa-Miyuki, 5 Kumi, AP Matsumi (Room 202)

Beppu-shi, Oita-ken, 874-0045

E-mail: ayemeng@yahoo.com

*The author would like to thank the anonymous referee for his/her valuable comments which have improved my manuscript.
} 


\section{General background}

The development experiences of East Asian countries are relevant for Africa today, because these countries at their early stages of development shared certain similarities with many African countries. At the time of their independence in the 1960s, income per capita in most Sub-Saharan Africa (SSA) was fairly comparable with that of East Asia. In fact, in the mid-1960's, the average income in sub-Saharan Africa was twice that of both South and East Asia while the average income in Africa is now well below half of that in East Asia (Commission for Africa, 2005). Accordingly, in the 1960s, much of the expectation was from SSA to perform more economic achievement than East Asia because of its large endowments of natural resources. As a matter of fact, in the early 1970s, many countries in Africa could point to significant progress in initiating process of economic and social development. Some level of industrialization had been initiated, levels of school enrolment had increased, new roads had been constructed, the indigenization of the civil service had advanced, and so forth. Furthermore, up to 1975, much of the investment in SSA was financed with domestic savings; thus, savings and investment during the period were relatively highly correlated (Mkandawire and Soludo, 1997).

Unfortunately, the prospect of African development that was promising in the 1960 s and early 1970s couldn't be sustainable and suffered a huge set-back due to structural, institutional, political, and policy constraints that will be thoroughly discussed in this thesis. Although there are considerable differences among the East Asian economies, but as a group, the East Asian economies ${ }^{3}$ consistently outperformed other developing regions since the 1960s, and their achievement has attracted the attention of policy makers everywhere. Hence, the East Asian economies have achieved a sustained and rapid growth in per capita income, undergone structural change on their economy and diversified their economic base over the last four decades. On the contrary, countries in SSA experienced with severe stagnation in the levels of per capita income, extreme poverty and trade volatility as a result of too much dependency on export of few primary commodities.

Hence, the annual growth in Real GDP per capita of SSA averaged about $0.44 \%$ over the period 1975-2004, compared to about $4.1 \%$ for East Asian economies during the same period. Thus, starting from quite similar per capita income in the early 1960s; East Asia and SSA have experienced a divergent development path and outcome.

\footnotetext{
${ }^{3}$ The 10 East Asian economies are China, Hong Kong, Taiwan, Indonesia, Japan, Korea, Malaysia, the Philippines, and Thailand. Japan is included because it made the transition to high-income status in the past four decades.
} 
The growing divergence in income per capita for selected East Asian and SSA countries is more evident in Table 1 below.

Table 1: Per Capita income in 1965 and 2000 (in current US\$)

\begin{tabular}{lrrr}
\hline Country & $\mathbf{1 9 6 5}$ & $\mathbf{2 0 0 0}$ & $\mathbf{2 0 0 0 / 1 9 6 5}$ \\
\hline Sub-Saharan Africa & & & \\
Cameroon & 140 & 580 & 4.1 \\
Congo, Rep. & 170 & 590 & 1.7 \\
Congo, Dem. Rep. & 330 & 90 & 0.3 \\
Cote D'lvoire & 200 & 680 & 3.4 \\
Ghana & 230 & 330 & 1.4 \\
Niger & 180 & 180 & 1.0 \\
Nigeria & 120 & 260 & 2.2 \\
Sierra Leone & 160 & 130 & 0.8 \\
South Africa & 540 & 3,060 & 5.7 \\
East Asia & & & \\
Japan & 910 & 35,420 & 38.9 \\
Korea, Rep. & 130 & 9.010 & 69.3 \\
Hong Kong, China & 690 & 26,410 & 38.3 \\
Singapore & 540 & 23,350 & 43.2 \\
China & 100 & 840 & 8.4 \\
Malaysia & 330 & 3,250 & 9.8 \\
Thailand & 140 & 2,020 & 14.4 \\
\hline
\end{tabular}

Source: World Development Indicators Database

In 1965, for instance, Korea Republic and Thailand had income per capita of $\$ 130$ and $\$ 140$ respectively; which had been lower than some SSA countries such as Ghana, Congo Republic, Cote d'Ivoire, Congo Democratic Republic and Sierra Leone. However, in year 2000, Korea and Thailand have registered a per capita income of $\$ 9,010$ and $\$ 2,020$ respectively. In the same time span, however, Ghana, Congo republic, Cote d'Ivoire have managed to increase their per capita income from $\$ 230$, $\$ 170$ and $\$ 200$ only to $\$ 330, \$ 590$ and $\$ 680$, respectively. In fact, Congo Democratic Republic and Sierra Leone didn't maintain the income per capita they had before 35 years and even went down from income per capita of $\$ 330$ and $\$ 160$ in 1965 to $\$ 90$ and $\$ 130$ in 2000 , respectively. By the same token, South Africa which is regarded as the best economy in Africa and Singapore in East Asia had exactly equal income per capita of $\$ 540$ each in 1965 . In year 2000 , however, South Africa registered a per capita income of $\$ 3,060$ where as Singapore achieved a per capita income of $\$ 23,350$ which was almost 7.6 times the performance of South Africa. Likewise, Sub-Saharan Africa's share in world exports fell from about $3.7 \%$ in 1980 to $1.5 \%$ in 
2002, while East Asia's share in world exports increased from $17.9 \%$ to $23.3 \%$ in the same period. Similarly, Sub-Saharan Africa's share in world imports fell from $3.1 \%$ in 1980 to $1.4 \%$ in 2002, while East Asia again increased its world import share from $13.1 \%$ to $20.8 \%$ in the same time span (Table 2 ).

Table 2: Shares of SSA and East Asia in World Merchandize Trade, 1980-2002

\begin{tabular}{ccccccc}
\hline Year & World & $\begin{array}{c}\text { Export } \\
\text { East Asia }\end{array}$ & SSA & World & $\begin{array}{c}\text { Import } \\
\text { East Asia }\end{array}$ & SSA \\
\hline 1980 & 100 & 17.9 & 3.7 & 100 & 13.1 & 3.1 \\
1985 & 100 & 15.6 & 2.5 & 100 & 15.2 & 2.1 \\
1990 & 100 & 16.9 & 1.9 & 100 & 15.9 & 1.6 \\
1995 & 100 & 21.6 & 1.5 & 100 & 21.9 & 1.6 \\
2000 & 100 & 24.3 & 1.5 & 100 & 21.1 & 1.3 \\
2002 & 100 & 23.3 & 1.5 & 100 & 20.8 & 1.4 \\
\hline
\end{tabular}

Source: UNCTAD Hand Book of Statistics, UNCTAD database

Though many developing regions, particularly East Asia have been transformed from exporters of primary products to manufactured products for the last three decades, Africa hardly benefited from the boom in manufactured exports. At around 30 per cent in 2000 , the share of manufactured exports in the continent's total merchandise exports had increased by only 10 percentage points compared to 1980 shares. The continent's share in world merchandise exports fell from 6.3 per cent in 1980 to 2.5 per cent in 2000 in value terms (Table 1.3). Similarly, Africa's share of total developing-country merchandise exports fell to almost 8 per cent in 2000, nearly a third of its value in 1980, while the share of world manufactured exports remained a little below 1 per cent. In contrast, East Asia's performance has been important with respect to both total merchandise exports and manufactures. Its share of global merchandise exports increased from 18 per cent in 1980 to 22 per cent in 2000, while its share of total developing-country merchandise exports increased from almost 60 to 72 per cent over the same period. Similarly, its share in global manufactures trade increased threefold, reaching 21.5 per cent in 2000 (Table 3). The value of East Asia's total exports recorded 7 per cent average annual growth over the period under review, compared to a mere 1 per cent for Africa.

Among all developing regions in the world, it is Africa that has the lowest share of manufacturing exports to total merchandise exports as shown in Figure 1. Whereas; East Asia has achieved a radical economic structural change and being 'center of excellence' in manufacturing products of all the developing world. 
Table 3: Export structure of Africa and East Asia by product category, 1980 and 2000

\begin{tabular}{|c|c|c|c|c|c|}
\hline \multirow{2}{*}{\multicolumn{2}{|c|}{ Region }} & \multicolumn{2}{|c|}{1980} & \multicolumn{2}{|c|}{2000} \\
\hline & & $\begin{array}{c}\text { All } \\
\text { Merchandise }^{a}\end{array}$ & Manufactures $^{\mathrm{b}}$ & $\begin{array}{c}\text { All } \\
\text { Merchandise }^{a}\end{array}$ & Manufactures $^{\mathrm{b}}$ \\
\hline \multicolumn{6}{|l|}{ Africa share in: } \\
\hline Global exports & & 6.3 & 0.8 & 2.5 & 0.8 \\
\hline Developing & & 20.3 & 7.8 & 7.9 & 3.0 \\
\hline \multicolumn{6}{|l|}{ Countries } \\
\hline $\begin{array}{l}\text { Developing } \\
\text { share in: }\end{array}$ & Asia & & & & \\
\hline Global exports & & 18.1 & 7.1 & 22.4 & 21.5 \\
\hline Developing & & 58.5 & 66.9 & 72.0 & 79.0 \\
\hline Countries & & & & & \\
\hline
\end{tabular}

Source: UNCTAD (2003)

'a' refers Standard International Trade Classification (SITC) 0-9., and 'b' refers SITC 5-8, less 68.

Figure 1: Developing regions' shares of manufacturing exports to total exports, 2002-2006.

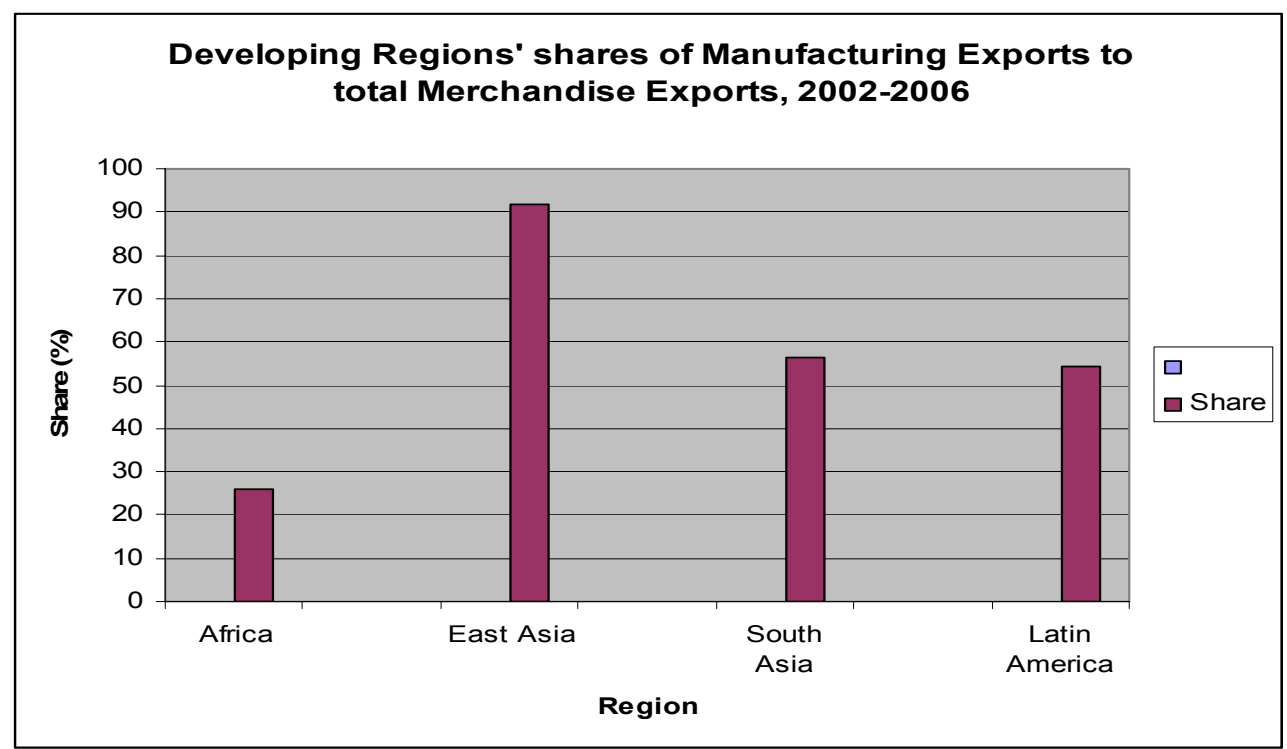

Source: UNCTAD (2008a)

What is more important is that the ratio of exports to GDP increased continuously in all East Asian countries in the past four decades as shown in Table 4. It is salient, for example, how Thailand increased its ratio of exports to GDP from 13 to 16 , to 21 and to 31 and finally to $52 \%$ (Table 4 ). 
Table 4: East Asian Countries increases in exports with respect to GDP (in \%)

\begin{tabular}{lccccc}
\hline \multirow{2}{*}{ Exp/GDP } & \multicolumn{5}{c}{ Period } \\
\cline { 2 - 6 } & $\mathbf{1 9 6 1 - 7 0}$ & $\mathbf{1 9 7 1 - 8 0}$ & $\mathbf{1 9 8 1 - 9 0}$ & $\mathbf{1 9 9 1 - 9 7}$ & $\mathbf{1 9 9 8 - 2 0 0 1}$ \\
\hline China & $\mathrm{N} / \mathrm{A}$ & 5.6 & 10.3 & 19.1 & 20.6 \\
Hong Kong & 55.6 & 64.1 & 90.0 & 116.8 & 114.6 \\
Korea & 5.5 & 22.8 & 30.9 & 25.1 & 37.5 \\
Singapore & 105.9 & 113.1 & 138.4 & 135.0 & 140.8 \\
Indonesia & 11.1 & 23.1 & 22.7 & 23.2 & 42.1 \\
Malaysia & 42.9 & 44.2 & 53.3 & 75.3 & 104.2 \\
Thailand & 13.8 & 16.3 & 21.6 & 31.6 & 52.4 \\
Philippines & 11.4 & 15.4 & 16.4 & 22.5 & 48.2 \\
\hline
\end{tabular}

Source: Sandee and Wengel (2004)

In line with this, international competitiveness of selected countries in the two regions has been displayed in Table 5. Interestingly, it has been evident that most of the East Asian countries had a negative international competitiveness index in the 1960's, just similar to the African countries. However, East Asian countries have managed to overcome their structural constraints and become internationally competitive; while their African counterparts are still experiencing negative competitive indexes which confirm the country's position as net importers of consumer and capital goods.

Table 5: International competitiveness index for selected SSA \& East Asian Countries, 1965 and 2004

\begin{tabular}{lcrlrr}
\hline \multicolumn{3}{c}{ Sub-Saharan Africa } & \multicolumn{3}{c}{ East Asia } \\
\hline Country & $\mathbf{1 9 6 5}$ & $\mathbf{2 0 0 4}$ & Country & $\mathbf{1 9 6 5}$ & $\mathbf{2 0 0 4}$ \\
\hline Cameroon & -0.38 & -0.06 & Indonesia & -0.38 & 0.17 \\
Ethiopia & -0.36 & -0.62 & Japan & 0.07 & 0.1 \\
Ghana & -.53 & -0.70 & Korea Republic & -0.33 & 0.06 \\
Kenya & -0.25 & -0.24 & Malaysia & -0.01 & 0.07 \\
Mauritius & -0.82 & -0.69 & Singapore & -0.11 & 0.08 \\
Nigeria & -0.49 & 0.24 & Thailand & -0.09 & 0.01 \\
Senegal & -0.62 & -0.21 & Taiwan & 0.09 & 0.11 \\
South Africa & -0.04 & 0.06 & The Philippines & -0.25 & -0.04 \\
\hline
\end{tabular}

Source: Own calculation based on the data obtained from UNCTAD Handbook of Statistics (2004) Note: International Competitiveness Index (ICl) is expressed as: $(X-M) /(X+M)$ where $X$ and $M$ are exports and imports respectively.

Generally, the value-added export oriented activities that have driven many dynamic developing economies are conspicuously absent in SSA. Linkage between local 
industries remains minimal and mostly superficial. The technological level of the existing industrial activities remains generally low.

The East Asia's success on one hand and the SSA's low performance on the other hand raises some crucial questions: Was the nature of policy package in East Asia very different from Sub-Saharan Africa? Were the effects of government interventions very different in East Asia? What might account for these differences between East Asia and Sub-Saharan Africa? Some economists argue that their rapid growth is explained by their ability to imitate foreign technologies. By adopting technology developed abroad, these countries managed to improve their production function substantially in a short period of time. In other words, these countries achieved a very rapid growth in total factor productivity (TFP). On the other hand, recent studies revealed that their exceptional growth can be traced to large increases in measured factor inputs: increases in labor-force participation, increases in the capital stock, and increases in educational attainment (Mankiw, 2003:234). However, although countries in East Asia had higher investment rates than others did, they had also a spectacular productivity growth far better than any developing countries (Thomas and Wang, 1997). Overall, East Asia's success was attributed to: (i) mobilization of domestic savings for investment including human capital and physical infrastructure; (ii) large FDI inflow used as alternative source of foreign currency and capital formation); (iii) shifting resources from less productive sectors to more productive sectors (vertical diversification); (iv) export-led growth; (v) sound macro-economic management (WB, 1993; Stiglitz et al, 2006) ; and (vi) Japan's role as a leading goose for East Asian development (Kwan, 1998).

On the other hand factors attributed for SSA's weak economic performance and poverty trap include: (i) the level of physical and human capital is so small that it falls below the threshold needed to start modern production process; (ii) very low levels of savings; (iii) high rates of population growth; (iv) a very low diffusion of technology from abroad (Sachs et al, 2004); (v) unfavorable economic policies; (vi) narrow based economy; and (vii) absence of a leading goose that may lead the flocks in the continent.

Furthermore, the macro-economic policies followed by most of SSA countries until the 1990 's had been un-favorable to economic growth. Imports and exports were subject to severe restrictions and under state ownership or control, the high walls of tariffs and export taxes that restricted international trade, over-valued exchange rates, wide margins for marketing parastatals, price and quantity controls that were aimed primarily at reducing food prices for urban consumers. 
One of the most remarkable features of growth in East Asian countries is that, it was accompanied by rising economic equality (Gerber, 2005). Since the 1950 s pioneering work of the economist Simon Kuznets, it was thought that growth in developing countries would first result in falling economic equality, followed later by rising equality (U-Curve relationship between income and equality). While Kuznet's work was based on measurements from a large number of countries, the East Asian experience has called into question the idea that economic growth in developing countries follows a "Kuznet's curve," in which equality first declines and then rises. Although the conditions that led to greater income equality were rooted in the unique historical experiences of each country, it is also evident that each of the East Asian countries had a similar set of highly visible wealth-sharing mechanisms such as land reform, free public education, free basic health care, and significant investments in rural infrastructure.

For all regions, it is Africa where income is most un-equal as measured by the Gini coefficient of 0.51 (Table 6). Uneven distribution of income in turn has perpetuated poverty and alienation in SSA. An increasing income inequality in Africa is mainly caused by concentration of the handful economic establishments including those few industrial plants and modern infrastructure in one or two urban conglomerations. Such inequality existed not only along regional lines, class, and ethnicity, but also going gender lines and hence modern formal sector employment in Africa continued to be a largely male domain" (Mkandawire and Soludo, 1999). Moreover, where regions were conterminous with ethnicity, such an uneven development could only fan the flames of ethnic conflicts

Table 6: Income Inequality Measures by World Regions

\begin{tabular}{lcccc}
\hline \multicolumn{1}{c}{ Region } & $\begin{array}{c}\text { Gini } \\
\text { Coefficient }\end{array}$ & $\begin{array}{c}\text { Share of top } \\
\mathbf{2 0} \%\end{array}$ & $\begin{array}{c}\text { Share of } \\
\text { Middle Class }\end{array}$ & Bottom 20 \% \\
\hline Africa & 0.51 & 50.6 & 34.4 & 5.2 \\
East Asia and Pacific & 0.38 & 44.3 & 37.5 & 6.8 \\
South Asia & 0.32 & 39.9 & 38.4 & 8.8 \\
Latin America & 0.49 & 52.9 & 33.8 & 4.5 \\
Industrialized Countries & 0.34 & 39.8 & 41.8 & 6.3 \\
\hline
\end{tabular}

Source: Deininger and Squire (1996)

Sub-Saharan African countries have still remained dependent on export earnings from a narrow base of few agricultural and mineral commodities for foreign exchange earnings (Table7) and have had to endure the consequences of all problems resulting from the fluctuation of commodity prices in world markets. 
About 17 of the 20 most important export items of Africa are primary commodities and resource-based semi-manufactures. In 1965 for instance, primary products account for $92 \%$ of Africa's merchandise export, and in 1988 it was still $88 \%$. On average, world trade in these products has been growing much less rapidly than manufactures. In fact, world trade in other primary commodities that account for an important proportion of total exports of Africa, particularly agricultural products such as coffee, cocoa, cotton and sugar, has been sluggish, with the average growth of trade in such products in the past two decades barely reaching one-third of the growth rate of world trade in all products (UNCTAD, 2003). World prices for many of the commodities that Africa exports declined between 1990 and 2000: Cocoa, Cotton, sugar and copper by over $25 \%$, coffee by $9 \%$ and minerals overall declined by $14 \%$ (WTO, 2001). As noted by $\mathrm{Ng}$ and Yeats (2002), one-half of traditional products in SSA experience average price changes of $50 \%$ or more during the 1990's.

Table 7: Main exports of selected Sub Saharan Africa countries

\begin{tabular}{ll}
\hline \multicolumn{1}{c}{ Country } & \multicolumn{1}{c}{ Exports } \\
\hline Angola & Oil, Diamonds, Minerals, Coffee, Fish, Timber \\
Benin & Cotton, Palm oil \\
Botswana & Diamonds, Copper, Nickel, Beef \\
Burkina Faso & Cotton, Animal Products, Gold \\
Burundi & Coffee, Tea, Sugar, Cotton, Hides \\
Chad & Cotton, Oil, Livestock, Textiles \\
Congo, Dem. Rep & Diamonds, Copper, Coffee, Cobalt, Crude oil \\
Congo, Rep. & Oil, Timber, Plywood, Sugar, Cocoa, Coffee, Diamonds \\
Cote d'lvoire & Cocoa, Coffee, Tropical woods, Petroleum \\
Equatorial Guinea & Petroleum, Timber, Cocoa \\
Ethiopia & Coffee, Hides, Oil seeds, Beeswax, Sugarcane \\
Gabon & Crude Oil, Timber, Manganese, Uranium \\
Kenya & Tea, Coffee, Horticultural products, Petroleum products \\
Mali & Cotton, Gold, Livestock \\
Mauritius & Sugar, Clothing, Tea, Jewelry \\
Niger & Uranium, Livestock products \\
Nigeria & Petroleum, Petroleum products, Cocoa, Rubber \\
Rwanda & Coffee, Tea, Hides, Tin ore \\
Senegal & Fish, Peanuts, Petroleum products, Phosphates, Cotton \\
South Africa & Gold, Diamonds, Metals \& Minerals, Cars, Machinery \\
Sudan & Oil, Cotton, Sesame, Livestock \& Hides, Gum Arabic \\
Zambia & Copper, Minerals, Tobacco \\
\hline Source: Osakwe & \\
\hline
\end{tabular}

Source: Osakwe (2007)

Theoretical analysis suggests that agricultural commodity prices fall relative to manufacturing products, because of relatively inelastic demand and because of the 
lack of differentiation among producers. On the demand side, the development of synthetic substitutes further displaces agricultural commodities as intermediate inputs, reducing at least the growth in demand. This drastic decrease of the SSA presence in world trade was not only the result of the deterioration of the terms of trades (due to low income elasticity of demand) in primary commodities, but also of the loss of competitiveness in manufactures. Consequently, Africa is the region that has the highest export concentration index in the world followed by South Asia (Figure 2). On the contrary, figure confirms that East Asia is one of the leading regions next to developed economies that have the lowest export concentration index.

Figure 2: Export concentration index by regions/economies of the World, 2006

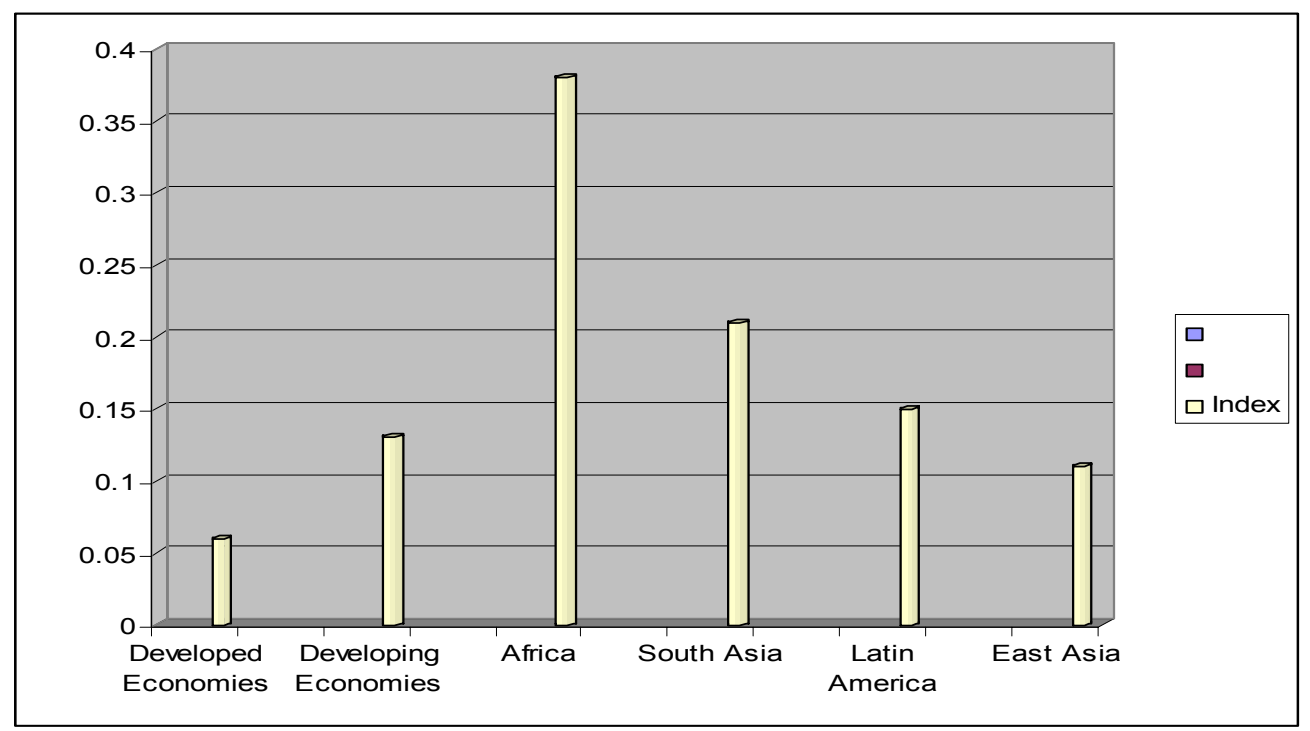

Source: UNCTAD (2008a)

Africa's export concentration on few primary commodities has led the countries to be more vulnerable for external shocks in addition to low of efficiency and productivity that led the region for further under-development. In line with this, the success of East Asian countries to shift from producing a low productive primary commodities to producing a more productive manufactured products reflects even latecomers are able to specialize in high growth areas if some of the pre-conditions are fulfilled. Thus, as Masuyama and Vandenbrink (2001) noted, unless a country diversifies critical supporting industries, the development of few industries alone will not produce growth in the economy. Hence, as Pinaud and Wegner (2004) noted, African economies still lack proper "shock-absorbers" to withstand internal (e.g. drought, floods, and political instability) and external (e.g. volatility of commodity prices and exchange rates) shocks alike. Thus, this situation makes a wake-up call to sub-Saharan Africa to 
re-evaluate the economic strategies and policies that have followed in the past with little achievement. Although diversification can't be expected to become the only panacea for SSA economic problems, it is one of the key measures for structural solutions (De Ferranti et al, 2002). Accordingly, the capacity of smoothing shocks highly depends on the ability of African policy makers to diversify their economies. That is why the economic report on Africa (2007) presents the theme of diversification as a new paradigm for Africa's development and the report argues that diversification is a prerequisite to achieving positive development in the continent. The case in point in this paper is, therefore, to examine and assess export diversification based on its vertical and horizontal dimensions and thereby to identify the relevant policy and institutional factors of vertical as well as horizontal export diversification.

\subsection{Defining vertical and horizontal export diversification}

There are two well-known forms/dimensions of export diversification from the supply side that may take place in developing countries, namely, horizontal and vertical diversification. Horizontal diversification can be materialized through (i) a larger mix of diverse and complementary activities within agriculture; and (ii) a movement of resources from low value agriculture to high value agriculture. On the other hand, an economy is said to be vertically diversified if and only if that country starts processing and exports value-added products that would have previously been exported in raw forms. Thus, vertical diversification involves a radical change in export structure and further uses of existing and new innovative export products by means of value-added ventures such as processing and marketing. Likewise, vertical diversification can also be more linked with higher learning possibilities that, in turn, may produce greater dynamic externalities than that of horizontal diversification. In other words, through forward and backward linkages, production of a diversified export structure is also likely to provide stimulus for the creation of new industries and expansion of existing industries elsewhere in the economy (Hirschman, 1958).

While both horizontal and vertical diversifications are targeted to attain three interrelated objectives: stabilizing earnings, expanding export revenues, and upgrading value-added; however, requirements for the two could vary considerably in terms of technological, managerial and marketing skills. Accordingly, it is vertical integration that may require more advanced technology, skills and initial capital investment than horizontal diversification. Hence, significant amount of investment on human capital through education and high rate of physical capital formation either by raising domestic savings or through FDI are pre-requisites for a country especially to achieve vertical diversification. Most often vertical diversification occurs when country's start processing commodities that were previously exported in raw form 
(Cramer, 1999). Fore-example, vertical diversification takes place by moving up the value chain to produce manufactured products as in Korea, China, and Malaysia. This, therefore, put into question for the policy advices of some researchers such as Owens and Wood (1997) that proposed Africa's emphasis should be on horizontal diversification through increasing the number of primary export products. On the other hand, horizontal diversification is achieved by producing non-traditional dynamic exports such as cut flowers as it has been started to be largely produced in Kenya, Uganda and Ethiopia to supplement or partially replace the traditional exports like coffee and tea. Thus, the goals, dimensions and forms of export diversification are clearly shown in Table 8 below.

Table 8: The goals, dimensions and forms of export diversification at country level

\begin{tabular}{|c|c|c|c|c|}
\hline \multirow[b]{2}{*}{ Dimension/Goal } & \multicolumn{2}{|c|}{ Stability-Oriented } & \multicolumn{2}{|c|}{ Growth-Oriented } \\
\hline & $\begin{array}{c}\text { Based on } \\
\text { existing } \\
\text { commodities }\end{array}$ & $\begin{array}{c}\text { Add new } \\
\text { commodities }\end{array}$ & $\begin{array}{c}\text { Based on } \\
\text { existing } \\
\text { commodities }\end{array}$ & $\begin{array}{c}\text { Add new } \\
\text { commodities }\end{array}$ \\
\hline $\begin{array}{l}\text { Horizontal } \\
\text { Diversification }\end{array}$ & $\begin{array}{l}\text { Adjust export } \\
\text { shares based on } \\
\text { co-variation of } \\
\text { export earnings } \\
\text { from individual } \\
\text { commodities }\end{array}$ & $\begin{array}{l}\text { Add new } \\
\text { commodities (and } \\
\text { possibly dispose of } \\
\text { existing } \\
\text { commodities) } \\
\text { based on } \\
\text { co-variation of } \\
\text { export earnings } \\
\text { from individual } \\
\text { commodities. }\end{array}$ & $\begin{array}{l}\text { Adjust export } \\
\text { shares based on } \\
\text { growth rates of } \\
\text { export earnings } \\
\text { from individual } \\
\text { commodities. }\end{array}$ & $\begin{array}{l}\text { Add new } \\
\text { commodities based } \\
\text { on growth rates of } \\
\text { world prices and } \\
\text { market niche. }\end{array}$ \\
\hline $\begin{array}{l}\text { Vertical } \\
\text { Diversification }\end{array}$ & $\begin{array}{l}\text { Adjust export } \\
\text { shares based on } \\
\text { a commodity's } \\
\text { ability to be } \\
\text { marketed in raw } \\
\text { or processed } \\
\text { forms in both } \\
\text { international and } \\
\text { domestic } \\
\text { markets. }\end{array}$ & $\begin{array}{l}\text { Add new } \\
\text { commodities based } \\
\text { on their flexibility to } \\
\text { be marketed in raw } \\
\text { and processed } \\
\text { forms, and to serve } \\
\text { international and } \\
\text { domestic markets. }\end{array}$ & $\begin{array}{l}\text { Introduce or } \\
\text { expand } \\
\text { value-added } \\
\text { activities and } \\
\text { import } \\
\text { substitution. }\end{array}$ & $\begin{array}{l}\text { Choose new } \\
\text { commodities based } \\
\text { on value-added and } \\
\text { import substitution } \\
\text { potential. }\end{array}$ \\
\hline
\end{tabular}




\subsection{Research objectives}

The main objectives of this study are the followings: (i) it develops a model for identifying the main determinants of vertical and horizontal diversification for East Asia and SSA economies; and (ii) by identifying the main determinants of export diversification, the study will figure out the specific areas in which the differences occurred and recommend the policy measures to be taken based on the major findings.

\subsection{Research questions}

(a) What are the key determinants for vertical and horizontal export diversification that require policy interventions?

(b) Over the past thirty years, most developing regions, especially East Asia have diversified their exports. Nevertheless, Africa is not part of this transformation. Why has Africa not diversified out of primary commodities?

(c) What would be the lessons from East Asia to SSA with regard to diversification in particular and economic growth in general?

Thus, in order to address the above research questions, the following research hypotheses have been tested in this study.

\subsection{Research hypotheses}

(a) Higher value of domestic capital and investment on education (human capital) may positively and significantly induce vertical and horizontal diversification and economic growth;

(b) FDI can increase competition, making domestic companies more efficient and stimulates sectoral and product diversification ;

(c) Human capital including education as well as health may positively enhance vertical and horizontal export diversification. However, since the levels of human capital and FDI are below the threshold level in SSA, thus their contribution to export diversification may not be satisfactory in SSA compared to East Asia;

(d) Natural resource endowment especially oil resources may negatively affects economic diversification through the 'Dutch Diseases' effect. However, if a country is endowed with more arable land then the ability of the economy to diversify is also high;

(e) The Country's level of development as measured by real per capita income as well as the domestic market size as measured by the size of population may positively induce export diversification; 
(f) Macroeconomic stability such as low inflation rate, openness, and a flexible and stable exchange rate system in a given country may create favorable conditions for export diversification;

(g) Political Instability is inversely related with export diversification due to the fact that rate of saving and investment tends to be low in countries with frequent wars.

\subsection{Significance of the study}

(i) Previous studies in this field have mostly treated 'export diversification' in aggregate forms, but this study is expected to fill the gaps in literature by examining diversification from its vertical and horizontal dimensions and contribute to the enhancement of knowledge in this area;

(ii) This study is also timely because almost African policy makers and UN agencies in their reports such as the Economic Report on Africa (2007) presents the theme of diversification as a new paradigm for Africa's development and they claim that, diversification is a prerequisite to achieving positive development in the continent;

\subsection{Limitation of this study}

This study may have some limitation such that few East Asian countries including Taiwan, China, Vietnam, Cambodia, Laos and Mynamar are not included in the study, mainly because of lack of consistent and complete data throughout the years that the study covers. The same is true for some African countries which are not included in this study because of lack of complete panel data throughout the study period.

Accordingly, the rest of this thesis is organized as follows: Section two deals with the theoretical framework and previous empirical works on export diversification; section three is going to identify and discuss the key determinants of export diversification; section four explains the research methodology and estimation methods; section five will come up with empirical analysis and main findings; and finally section six provide concluding remarks and policy considerations.

\section{Theoretical framework and previous empirical studies on export diversification}

The concept of international trade as an engine of 'economic growth' dates back to the time of Adam Smith. However, since the 1980s openness, trade liberalization and out-ward oriented policies became popular policy prescriptions among economies and policy makers for achieving economic growth. Parallel to the outward-orientation 
paradigm, another hypothesis related to structural changes in exports and increased diversification of exports gained even greater popularity in the literature (e.g. Ali and Siegel, 1991; Amin Gutierrez de Pineres and Ferrantino, 1997). Hence, the question that has to be asked is: what are the theoretical reasons that export diversification is conducive to economic growth?

Firstly, the traditional argument for export diversification is based on its role in reducing export earnings instability caused by cyclical fluctuation in international commodity prices. Many countries that are commodity dependent often suffer from export instability arising from inelastic and unstable global demand so export diversification is one way to alleviate these particular constraints. Because of its impact on domestic demand, export instability could discourage necessary investments in the economy by risk-averse firms, increase macroeconomic uncertainty and be detrimental to longer term economic growth. Export diversification could therefore help to stabilize export earnings in the longer run (Ghosh and Ostry, 1994; Bleaney and Greenaway, 2001).

In a similar line of reasoning, Love (1983) that the more highly concentrated a country's exports, the lower is the probability that fluctuations in one direction in some of its exports will be offset by counter fluctuations or stability in others. Hence, the need for diversification which has tended to be equated with the expansion of manufactured exports. By the same token, Labys and Lord (1990) states that export diversification offers a means by which countries can combat earnings uncertainty, when these earnings derive from a few primary commodities and, at the same time, can increase their revenues from investment in the production of products with market growth potential. Studies have been also revealed that unstable export earnings make it difficult for a country to plan capital imports, destabilize consumption, and can adversely affect export earnings trends (Maizels, 1987).

Secondly, the relatively new arguments mainly derived from the endogenous growth theory are based on the fact that export diversification is beneficial not only for offsetting export earnings fluctuations, but it has also a very strong and dynamic comparative advantage. Hence, the dynamic elements of export diversification include demand and supply changes, industrial capability, risk aversion, environmental considerations, and changes in commercial policies (Ssemogerere et al., 1994). The argument on the demand side is that exporters facing autonomous factors such as rising incomes and change in taste would push countries to diversify their exports towards income-elastic ones. Similarly, the supply side argument is in terms of production structure adjustment to changes in production technology and input mix, better land utilization, the introduction of new skills, changes in the availability of 
imported inputs, in response to potential competitors. All these factors enable a country to diversify into products of different price elasticity of export supply. In short, endogenous growth theory suggests that export diversification affects long-run growth with its accompanying increasing returns to scale and dynamic spillover effects as a result of new techniques of production, management or marketing practices potentially benefiting other industries (Amin Gutierrez de Pineres and Ferrantino, 2000).

Endogenous growth models such as Matsuyama (1992) emphasize the importance of learning-by-doing in the manufacturing sector for sustained growth. Related to export diversification, there could be knowledge spillovers from new techniques of production, new management, or marketing practices, potentially benefiting other industries (Amin Gutierrez de Pineres and Ferrantino, 2000). Similarly, Agosin (2007) develops a model of export diversification and growth and finds that countries below the technological frontier widen their comparative advantage by imitating and adapting existing products. By the same token, Glyfason (2002) identifies the key factors of economic growth and also the link between those factors and export diversification using the model as shown in Figure 3.

\section{Figure 3: Six determinants of growth}

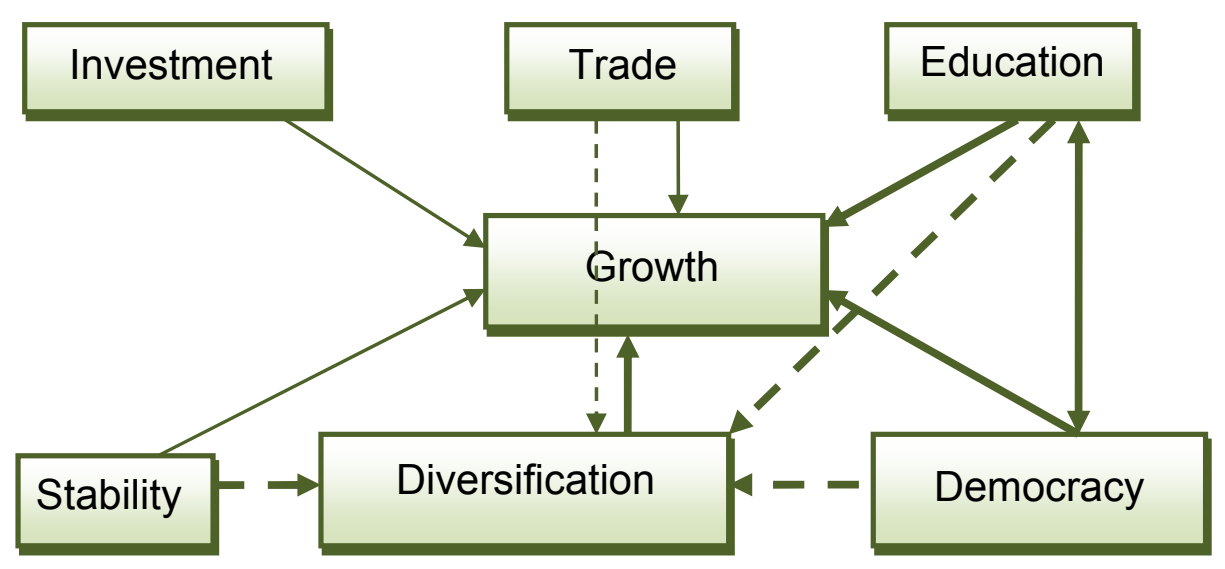

Source: Glyfason (2002)

The model above explains that there are about six different kinds of producible capital that are needed to sustain economic growth. First, saving and investment are obviously necessary to build up physical capital. Second, education is needed to build up human capital. Third, macroeconomic stability encourages the accumulation of 
financial capital, i.e. financial depth, which helps lubricate the wheels of production and thus increases economic efficiency and growth. Fourth, increased trade with the rest of the world helps to technology transfer as well as to strengthen the capital base of domestic activity. Fifth, increased democracy can be viewed as an investment in social capital by which is meant the infrastructural glue that hold society together and keeps it working harmoniously. Sixth, diversification is expected to increase income by expanding the possibilities to spread investment risks over a wider portfolio of economic sectors. Moreover, through forward and backward linkages, production of a diversified export structure is also likely to provide stimulus for the creation of new industries and expansion of existing industries elsewhere in the economy. Furthermore, the model indicates that factors that are good for growth are also good to stimulate export diversification.

The structural models of economic development propose that countries should diversify from primary exports into manufactured exports in order to achieve sustainable growth (Chenery, 1979; Syrquin, 1988). Similarly, the Prebisch-Singer thesis postulates that 'vertical export diversification' could reduce declining terms of trade for commodity-dependent countries. Al-Marhubi (2000) in a conventional cross-sectional country growth regression adds various measures of export concentration to the basic growth equation and does find that export diversification promotes economic growth, and these findings are robust to different model specifications. Also in a cross-sectional regression, Agosin (2007) finds that export diversification has a stronger effect on per capita income growth when a country's exports grow faster than alone. Lederman and Maloney (2007) in a dynamic cross-country panel model also find evidence in support of diversification-led growth. Likewise, within country studies by Amin Gutierrez de Pineres and Ferrantino (1997) as well as Herzer and Nowak-Lehmann D. (2006) have examined the link between export diversification and economic growth in Chile, and their findings do suggest that Chile has benefited greatly from diversifying its export base. Models in the product cycle literature (Vernon, 1966; Krugman, 1979; Grossman and Helpman, 1991) also imply a link between export diversification and growth.

Furthermore, Hausmann and Rodrik (2003), Hausmann, Hwang, and Rodrik (2006), and Hausmann and Klinger (2006) analyze the benefits of export diversification and exports in general for economic growth, both empirically and theoretically. In their framework, economic growth is not driven by comparative advantage but by countries' diversification of their investments into new activities. An essential role is played by the entrepreneurial cost-discovery process. According to the model of Hausmann and Rodrik (2003), entrepreneurs face significant cost uncertainties in the production of new goods. If they succeed in developing new goods, the gains will be socialized 
(information spillovers) but the losses from failure end up being private. This leads to an under provision of investments into new activities and a suboptimal level of innovation. The bottom line is that according to Hausmann and Rodrik (2003), the government should play an important role in industrial growth and structural transformation by promoting entrepreneurship and creating the right incentives for entrepreneurs to invest in a new range of activities.

It is also evident that there are knowledge spillovers or learning by doing from export diversification (Amin Gutierrez de Pineres and Ferrantino, 2000). The basic thrust underlying such a hypothesis was based on "product cycle" models. In this context, innovative activity by the north (developed countries) leads to an increasing diversity of products, while imitative activity by the south (LDC) leads to an increasing diversity of products being produced and exported from low-wage locations (Amin Gutierrez de Pineres and Ferrantino, 1997). By the same token, the product life cycle theory of Vernon (1966) argued that as the result of imitative activities, the comparative advantage of many developing countries has shifted from the export of primary products to manufactured products over time from one country to another. This happens because these goods go through a product life cycle. Once the product is invented, then overt time becomes more standardized as consumers and producers gain familiarity with its features. One of its strength is that it can explain exports of sophisticated manufactured goods from countries that have shortages of skilled labor and capital. Standardized manufacturing routines are increasingly common, using low-skilled and semi-skilled labor in assembly type operations.

Moreover, according to the catching-up product cycle theory, industrial structure evolves as an economy develops, from the simplest (imported) technology to more and more sophisticated functions of the production cycle. The sequential upgrading of production technology and industrial structure is called the "flying geese" model because the industrial structure evolves in a pattern resembling the $\mathrm{V}$-formation of a flock of flying geese (Kwan, 1998). This same flying geese model is typically used to describe the relationship among the economies in the East Asia region. The image captures the connections between the industrial structures of the Asian economies at different stages of development and the dynamic, sequential nature of their development. Japan leads the East Asian flock, followed by Korea and Taiwan, and then the other, later-developing economies of the region. Thus, the flying geese model depicts the latecomers replicating the development experience of the economies ahead of them. Generally, the product cycle theory emphasizes that commercial successes of consumer durables depend on product development mainly based on cost-cutting mass production and the use of known technology, rather than on technological breakthroughs. In this case, the East Asian development experience is a 
good example of how late-comers can develop through imitation, as long as they put the necessary pre-conditions in places, such as human capital, physical capital, infrastructure, and so forth.

Thus, the volume of total exports in real terms is determined by the three main factors: the world demand for exports of the given commodity, competitiveness of the given product and the degree of export diversification of that country (Athukorala, 1991). For instance, in the 1960s, agricultural export performance was similar among Indonesia, the Philippines and Thailand, both in nominal and real value terms. But in the decades since then, the three countries have shown different performances in agricultural exports. The main important factor resulting in the differences is the ability of diversification and adjustment of agricultural exports when the market conditions changed.

There are more empirical works which verify how export diversification induces growth. Agosin (2005) conducted a cross country study on the effects of export diversification on growth in a group of Latin American and Asian countries and found that controlling for other variables that affect growth, export diversification, alone and interacted with per capital export volume growth, is found to be highly significant in explaining per capita GDP growth over the 1980-2003 period. Similar empirical research findings by Sachs and Warner (1997), or more recently by Glyfason (2004) and De Ferranti et al. (2002) suggest that export concentration is indeed statistically associated with slow growth, in particular when export concentration reflects the predominance of primary products, as it usually does. Herzer et al (2004) also found a long-run statistical association between growth and export diversification on the basis of time-series data from Chile.

Generally, various literatures on export diversification indicate two ways of transmission channels from export diversification to growth. The first argument is that developing countries exports tend to be concentrated on a few products, often commodities, with very volatile demand. This translates into high income instability, which in turn provokes high growth volatility. Export diversification in this setting has the advantage of creating a more stable income inflow. The second effect is associated with the dynamic benefits generated by diversifying comparative advantages in terms of the spillovers in the economy as a result of having a more diversified production structure (Hausmann and Klinger, 2007). In sum, diversification from the supply side can take place in developing countries either vertically or horizontally; but mainly through both dimensions.

Export diversification may also result more endogenously from a growing demand for a variety of goods as a country's income increases (Imbs and Wacziarg, 2003:82). In other words, production patterns respond to changes in the structure of demand and 
then generate increasing sectoral diversification through the "Engel" effect. The most influential research on diversification by Imbs and Wacziarg (2003) has identified two stages of diversification in the process of economic development. First, poor countries tend to diversify as their incomes rise; then, the level of diversification will reach to a turning point and later begin to become more specialized. In this case, the diversification of an economy could be related to its development level, measured by GDP per capita, through an inverted-U shaped relation. Therefore, a country ought to undertake investment in such a way that this turning point occurs as a result of attaining deep diversification. Because, it is only after the attainment of deep diversification that countries can shift to the second stage that tends towards specialization. Thus, the stages of diversification will follow the following steps:

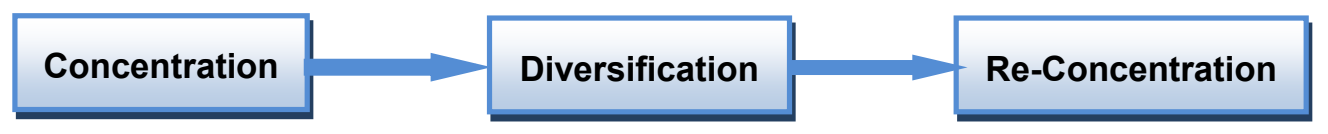

The two-stage diversification process from economic history has been registered both in open and closed economies. The difference between the two is that the turning point after reasonable and sustainable development has been achieved at a much earlier point for open economies compared to the case for closed economies (Imbs and Wacziarg 2003). Similarly, Carrere et al. (2007), have studied the pattern of export diversification of 159 countries over 17 years and confirmed that re-concentration of exports after successful diversification will start above a threshold of PPP $\$ 24,000$. This implies that diversification occurs mostly at the extensive margin for low- to middle-income countries, as new export items multiply and are marketed at increasingly large initial scales. This implies that most developing countries are actually in the diversifying stage over the course of their development path. Whereas, almost all developed countries today are in the stage of re-concentration after they successfully passed the diversification stage in the past. From a policy perspective, it thus appears as a key element of the economic development process in developing countries. In actual fact, export diversification in developing countries implies the broadening of comparative advantages into new sectors. It is only if countries first diversify and then specialize in activities in which a country has comparative advantage can lead to greater efficiency allocation. What therefore explains the two stages of diversification?

According to the neoclassical economic theory, when a relatively poor country starts accumulating capital and enters the cone of diversification, the Rybczynski effect will occur: the share of the capital-intensive aggregate should go up. This makes the aggregates shares more equal and, because the country starts producing capital-intensive goods, this should reduce industrial concentration. Another reason is 
related to the structure of preferences argument that if agents have non-homothetic preferences, their consumption pattern will change as income grows. These Engel effects are generally understood as implying an expanding diversity of the goods consumed. In other words, production patterns respond to changes in the structure of demand and then generate increasing sectoral diversification. According to Acemoglu and Zilibotti (1997), development goes hand in hand with the expansion of markets and with better diversification opportunities. Saint-Paul (1992) also presents a model where limited access to financial markets affects the pattern of domestic production in developing countries, and hence sectoral diversification is the only available means to diversify away sector-specific income shocks and smooth consumption. On the other hand, in the endogenous growth models, greater diversifications of exports occur through learning-by-doing and learning-by-exporting and through imitation of developed countries (Amin Gutierrez and Ferrantino, 1997:376). In the same token, what appears to be crucial is also creating an environment that creates competition and thus to acquire new skills and this can be performed through exports. Without the pressure from outside competitive forces, acquisition of human capital, and thus overall economic growth, may be slow (Husted and Melvin, 2007).

At this juncture, a genuine question may arise such that if countries get back to re-concentration, why should they need to diversify? The point is that, there is a fundamental difference between countries that are in the first stage of concentration and countries that come-back to re-concentration. The main difference is that the former specializes largely in primary products whose relative prices are falling from time to time; whereas the latter specializes in high value added and knowledge intensive products whose relative prices are on a rise from time to time. Theoretically, this argument can be supported by the famous "Stolper-Samuelson" specialized -factor pattern theorem as follows: (i) the more the factor is specialized, or concentrated, in the production of a product whose relative price is rising, the more this factor stands to gain from the change in the product price; (ii) the more the factor is concentrated into the production of a product whose relative price is falling, the more it stands to loose from the change in product price.

Therefore, combining the findings of new trade and endogenous growth theory suggests that the interplay of economies of scale, externalities and national or international spillovers of knowledge and technology can be crucial for the diversification experience of "late-comers". Hence, diversification is not a phenomenon that contradicts the notion of comparative advantage especially in the case of for developing countries. Instead, it implies the acquisition of new comparative advantages or broadening comparative advantages into new sectors. In other words, diversification should be seen as a dynamic process, not as a static one. There are 
three keys to a successful industrialization and economic diversification strategy. One is to have a clear government strategy - not to be confused with direct state involvement in running industries, which we all acknowledge to be a thing of the past. It is a well-known fact that in South East Asia, governments took an active role in promoting industrialization, intervening at strategic points through regulation and incentives and mobilizing resources where appropriate. The second factor in promoting industrialization and diversification is regional integration. The third is a robust private sector response. Stable and predictable macroeconomic and political and regulatory environments, as well as a fair and open international trading framework, are among the basic requirements of the development process.

Hence, the ability to shift production and exports from customary products to more dynamic ones without losing the expertise obtained in the former is a crucial ingredient for breaking the vicious cycle of dependence and turning it into a virtuous cycle of dynamism and development. A stable economic environment at the macro level, a supportive international trading system and entrepreneurial drive at the micro level are prerequisites but, these by themselves, are not sufficient to spur the structural transformation of economies. Governments have to act on certain critical areas, and entrepreneurs have to adopt modern business strategies consciously.

In sum, motivated by the desire to spread risks, raising capacity utilization and increasing total export proceeds, export diversification has been the concern of most developing countries. Despite such a concern, however, very few developing countries in East and South East Asia as well as developing America (such as Brazil, Mexico, Argentina, and Chile) have actually managed to achieve a diversified export structure with greater volume of manufacturing products. On the contrary, the overall performance of Africa (except few countries such as Mauritius, South Africa, Seychelles, Tunisia, and Botswana) in terms of export diversification has been far from satisfactory and most countries continued to be totally dependent on a few agricultural and mineral exports. The prime barriers of effective export diversification in Africa include policy distortions, poor infrastructure services, high risks and high transaction costs that inhibit competitiveness. Thus, diversification requires substantial physical and human capital (investment on education), stable and predictable macroeconomic and political environments, as well as a fair and an open trading framework. In line with this, the ability to shift production and exports from customary products to more dynamic ones without losing the expertise obtained in the former is a crucial ingredient for breaking the vicious cycle of dependence and turning it into a virtuous cycle of dynamism and development. 
Generally speaking, most researchers would agree that export diversification matters for economic growth and it is especially important for developing countries (Amurgo-pacheco and Pierola, 2008) to attain three interrelated objectives: stabilizing earnings, expanding export revenues, and upgrading value-added.

\section{Determinants of vertical and horizontal export diversification}

Based on the theoretical analysis discussed above as well as some related empirical works such as: Osakwe (2007); Gylfason (2002); Bebczuky and Berrettoni (2006); Elbadawi (1999); Wood and Mayer (2001); Munemo (2007); Herzer and Nowak-Lehmann (2006); Parteka and Tamberi (2008); and others; the following determinants for export diversification have been identified:

\section{(i) Physical capital}

Traditional growth theory looks at capital accumulation as the most important determinant of export diversification. The physical capital of a given country (capital stock) consists of domestic-owned physical capital and foreign-owned physical capital. Accordingly, gross fixed capital formation as a share of GDP is used to capture the influence of the domestic investment in a similar fashion as Olofsdotter (1998) and others. Similarly, foreign capital is often captured by the ratio of ratio of FDI to GDP. Thus, it is imperative to further breakdown physical capital into domestic and foreign capital and examine their separate effects on both vertical and horizontal diversification.

\section{ii) Domestic investment}

Unless a country commits a sufficient portion of its national income to building domestic capital stock, it is unlikely to be able to diversify. Ben Hammouda et al (2006), underlines that investment is vital for an economy to diversify; since as the level of investments increases, there is a tendency for economies to become more diversified. While increasing the level of domestic investment helps promote diversification, the sectoral allocation of investment is also crucial. To boost diversification, governments should therefore design incentive mechanisms to encourage domestic investment in new activities. Accordingly, there is empirical evidence that a country which invests a bigger proportion of its output in capital formation is likely to accumulate the necessary infrastructure and equipment more rapidly to allow the country to diversify its production basis (Habiyaremye and Zeisemer, 2006). Chile and Botswana provide a good example for such reasoning, where the accumulation of domestic capital is related to developing other sectors than the exploitation of their primary commodities. 
Likewise, the UN Under Secretary-General and Executive Secretary of the UN Economic Commission for Africa, Abdoulie Janneh (2009), argued that, "for the business sector in Africa to grow and contribute to poverty reduction and economic development, domestic investment as a proportion of GDP must improve from an average $18 \%$ in Sub-Saharan Africa to between $25 \%$ and $30 \%$, which is the average rate in East Asia.

\section{iii) Foreign direct investment (FDI)}

There are proponents and opponents about the benefits of FDI in an economy. In the standard neo-classical model, opening international capital markets generates flows from capital-abundant towards capital-scarce countries, thereby accelerating convergence (hence short term growth) in the poor countries. In a more sophisticated context, productivity may also increase since capital inflows may relieve the economy from credit constraints and thus allow agents to undertake more productive investments (Acemoglu and Zilibotti, 1997). Similarly, Saint-Paul (1992) and Obstfeld (1994) suggest that international capital mobility may affect productivity independently of investment, by promoting international risk diversification which induces more domestic risk taking in innovation activities, thereby fostering growth. Thus, FDI has many benefits for economies, particularly developing economies. Accessing foreign savings can help economies grow faster and, in the case of developing economies, catch up with rich economies (Barro, 1997). FDI can increase competition in the host economy, making domestic companies more efficient and stimulates sectoral and product diversification. It is also evident that FDI is an important vehicle for the transfer of technology, contributing relatively more to growth than domestic investment.

On the other hand, there are also some arguments against the benefits of FDI such that FDI could be a threat to young growing companies/firms with limited capital outlays as compared to the multi-national corporations (MNCs); since the young domestic firms will be unable to compete with the MNCs with huge capital outlays. As a result, this could possibly lead to the extinction of such small local firms. However, the experience of emerging economies especially FDI driven economies in East Asia confirm that FDI and domestic investment are, in fact, complementary with each other. For instance, FDI would play a complementary role with domestic investment by working together with local firms in the form of 'joint ventures'.

All in all, there is a common consensus that the benefit aspects of FDI outweigh the cost. Nevertheless, the higher productivity of FDI holds only when the host country has a minimum threshold stock of human capital. Thus, FDI contributes to export diversification only when a sufficient absorptive capability of the advanced technologies is available in the host economy. However, the African region has not 
been successful in attracting a large amount of FDI compared to East Asia and Latin American regions; mainly due to the fact that Africa has lack of adequate skilled labor force that may participate in the investment sectors.

\section{iv) Human capital}

Human capital is part of the investment climate of an economy and is generally considered as complementary factor of physical capital. In this study, human capital has been proxied by the 'education' variable as well as 'health' variable. The education component of human capital refers skilled labor, that is, skills acquired by individuals through a process of investment in education and training. Likewise, the health component of human capital which is often proxied by 'life expectancy' at birth is also expected to play a positive role for enhancing export diversification and growth in a country's economy. For example, from 1975 to 2000, GDP per capita in Southeast Asia tripled while life expectancy rose from 54 years to 67 years (ADB 2001).Thus, it then becomes logically imperative that human capital should indeed be treated as a factor input just like physical capital and labor (Roskamp and Mc Meekin, 1968). Accordingly, the new trade and endogenous growth theories have emphasized human-capital accumulation and technological innovations are the main engines of structural diversification and growth. Human capital in the form of knowledge is said to make the difference between poverty and wealth. As World Bank (1999:1) noted:

"Ghana and the Republic of Korea started with almost the same GNP/capita in 1960. Thirty years later the Korean GNP/capita had raised more than six times, the Ghanaian GNP/capita was still hovering at the same level (in 1985 prices). Accordingly, the evidence shows that half the gap could be explained in terms of traditional factor inputs (in classical economic terms: land, labor, and capital), the other half was attributed to knowledge as a factor of production."

Development policy targeting technology acquisition and the reduction of the technology gap must be aimed at facilitating the interaction between technology flows and human skills (Abramovitz, 1986). That was why East Asian countries have been successful in narrowing the technology gap in a few decades, and their educational attainment is credited for much of this achievement (Lall, 1992). Hence, as Nelson and Phelps (1966) suggests, a large stock of human capital makes it easier for a country to absorb the new products or ideas that have been discovered elsewhere. As a result, a follower country with more human capital tends to grow faster because it catches up more rapidly to the technological leader.

By the same token, endogenous growth theory has shown that differences in the level of countries' human capital lead to differences in their capacity (i) to invent new technologies, (ii) to adapt and implement technologies developed elsewhere, and (iii) 
to attract other factors such as investment in physical capital, which also contribute to economic growth and development.

\section{v) Infrastructure}

It is obvious that infrastructural development in any country would reduce production costs, increase efficiency and productivity and thereby to maximize profitability. Moreover, adequate infrastructure provides a very significant stimulus to private sector development, sectoral and product diversification. Moreover, good infrastructure is a necessary condition for foreign investors to operate successfully (Wheeler and Mody, 1992).

The combined effects of low investment levels and poor infrastructure, together with dependence on primary commodities in SSA, has led to very low productivity levels and a correspondingly low level of capital accumulation that has been insufficient to trigger a sizable manufacturing activity (Sachs et al, 2004). Cross-country studies by Canning and Bennathan (2000) indicates that infrastructure; particularly telecommunications infrastructure significantly increases economic growth. Thus, new market access alone would not spur investment in new supply capacity unless it is supported by decent roads, efficient ports, and the technical capability to produce and distribute goods of sufficient quality which collectively called 'exporting infrastructure'(Stiglitz, 2006). In this case, Infrastructural development is one of the key pre-requisites for better diversification.

\section{vi) Inflation}

Macroeconomic stability plays a key role for the success of diversification efforts. Moreover, macroeconomic stability provides the private sector with a stable environment in which entrepreneurs and consumers are able to plan and invest and focus on production and performance rather than the environment in which they operate. In other words, macroeconomic stability is central to sustained growth. Otherwise, macroeconomic instability such as high levels of inflation damage diversification prospects and the tendency under such circumstances is for increased concentration with little opening-up to new export sectors. Similarly, a high inflation environment is not conducive to the development and maturation of new sectors, nor is it supportive of an environment that fosters other determinants of diversification so that they have significant impact. Because, a high rate of inflation is generally harmful to growth because it raises the cost of borrowing and thus lowers the rate of capital investment; but at low, single-digit levels of inflation, the likelihood of such a trade-off between inflation and growth is minimal. At the same time, highly variable inflation makes it difficult and costly to forecast accurately costs and profits, and hence investors and entrepreneurs may be reluctant to undertake new projects. However, a 
moderate but a stable inflation may not slow down diversification. It is only an inflation rate which is quite high such as in the 15 to 40 percent range may become prejudicial to growth (Bruno and Easterly, 1995).

\section{vii) Exchange rate}

It has been assumed that a depreciating currency is an appropriate macroeconomic fundamental to support increases in existing exports and ease potential exportable products into new markets. Such a result supposes two elements. First, it pre-supposes that the country already has export potential and that the depreciation has the price effect of making the exports cheaper for the foreign markets. It further assumes price-elastic export demand. Second, it also assumes that depreciation is supported by sound macroeconomic fundamentals and can maintain competitiveness in the international market.

The classical approach to devaluation as a remedy for a balance of payments deficit cites shifts on both expenditure and production; expenditure shifts away from imports toward domestic products, and production shifts out of goods and services for domestic use into exports. Both shifts contribute to the reduction in domestic absorption required to eliminate the balance of payments deficit. Opponents of the classical view make two apparently contradictory arguments about the effects of nominal devaluation. Much of the structuralism literature argues that nominal devaluation leads to contraction of demand and output. But another body of literature focuses on inflationary consequences. However, it is evident that inflation is mainly caused by the expansionary fiscal and monetary policies rather than the exchange rates.

Although policy prescriptions have generally assumed that exchange rate depreciation would stimulate exports and curtail imports, it is not always true in all cases. For instance, Abeysinghe and Yeok (1998) empirically investigated the impact of currency appreciation on exports in the case of Singapore and found that in the presence of high import content, exports are not adversely affected by currency appreciation because the lower import prices due to appreciation reduce the cost of export production. This implies that the cushioning effect outweighs that of the effect of productivity gains on export competitiveness. Accordingly, Singapore is a particularly interesting case study as it has been experiencing sustained export growth despite an appreciating currency.

\section{viii) Degree of openness}

Generally, there is a growing consensus that suggests trade liberalization is vital; but it should follow a gradual approach. The Proponents of a gradual approach to trade liberalization point out that there are inherent constraints in countries that limit their 
ability to build a competitive advantage to export new products in a short period of time. As such, they argue for policy space that would allow them to pursue policies conducive to diversification through industrialization (Economic Report on Africa, 2007). Similarly, the catching-up theory explained that other things being equal, the faster the rate of innovation in advanced economies, the higher the scope of growth via imitation for laggard economies. Given that technology flows from the leader to the follower via international trade, ceteris paribus, the higher the degree of trade liberalization (openness), the faster the diffusion process will be (Baumol et al., 1994). Similarly, the World Bank (1993) found that openness had a statistically positive impact on total factor productivity (TFP) growth in its study of 51 countries for the 1960-89 periods. As a result, openness is positively associated with diversification.

\section{ix) Income per capita}

The level of development, as measured by real per capita income, is also one of the control variables. The idea is that countries at higher levels of income are likely to be more diversified than those at lower levels of income (Imbs and Wacziarg, 2003). However, at a certain stage of income per capita; usually when a country reaches to high income developing countries or further into developed countries, diversification becomes decreasing and a the economy will start to re-concentrate on selected specialized products. However, since almost all countries in this study except Japan are classified as developing countries, the relationship between income per capita and export diversification is expected to be positive.

\section{x) Foreign aid}

The relationship between foreign aid and export diversification is not conclusive. The traditional justification for foreign aid is that it eases the resource constraint of developing economies, especially on the supply side (Munemo et al., 2007). In this case, therefore, foreign aid is expected to have a positive coefficient for export diversification.

However, foreign aid can also harm export diversification; due to its potential impact on the real exchange rate. The idea is that large aid inflows have the potential to increase the price of non-traded goods leading to a real exchange rate appreciation and loss of export competitiveness. This effect is likely to be more severe in economies with capital market imperfections and in the manufacturing sector - where there are externalities such as learning-by-doing (Osakwe, 2007). Consequently, by appreciating the real exchange rate and reducing output in the export sector, aid leads to a loss of productivity and so has a negative effect on the development and expansion of manufacturing activities. According to Van Wijnbergen (1985), one of the explanations for lack of export diversification in Africa is due to the negative role of foreign aid. From the 
preceding discussion, therefore, it can be assumed that the foreign aid variable may have either a positive or negative relationship with export diversification.

\section{xi) Political stability}

Both political stability and macroeconomic stability are essential if markets are to work effectively in guiding resource allocation and fostering confidence of economic agents in the economy. Almost all the rapidly growing East Asian countries experienced periods of political stability during the key development years and such political stability has enabled governments in East Asia to materialize long-term plans into reality and to avoid short-termism. On the contrary, political instability in most of SSA countries was one of the factors for Africa's poor economic performance for the last 3-4 decades. For instance, a relatively better political stability combined with sound macro-economic policies in Africa in recent years have resulted an encouraging economic performance.

\section{xii) Market size}

The domestic market size of a country can be proxied by the size of its population. Endogenous growth theory indicates that, countries with a larger population and a larger market size are expected to grow faster because of scale economies. Countries with larger population sizes are more likely to develop varied skills that can be deployed in different fields. Likewise, countries with population spread over large geographical areas can benefit from distinct regional specialization, by extension, to large mix of national export diversification. Although working age population (between 15 and 65) is the best variable to measure the scale effects, the data on labor force have major problems of measurement, especially for the poorer countries. In this case, therefore, the total population instead of the working age population can be considered (Barro. and Sala-i-Martin, 1999).

\section{xiii) Natural resource endow ment}

Natural resource endowment in this study is proxied by two variables: Arable land ratio and 'oil dummy'. Although World Bank (2002) advocates that resource abundance could bring about technological progress and new knowledge, various studies including Sachs and Warner (2001) find a negative relationship between resource abundance and growth. According to Glyfason (2001) natural resource-based economies might not have the incentives to heavily invest in human capital accumulation. The Rybczynski theorem also suggests that development of new natural resources, such as oil or gas may retard development of other lines of production, such as manufactures through the "Dutch Diseases" effect. The 'Dutch Disease' effect was named after the experience of the Netherlands, where increased 
oil and gas revenue $s$ in the late 1950s resulted in the appreciating of the Dutch Guilder and loss of export markets and de-industrialization. Similarly, Wood and Mayer (1998) have emphasized that the concentration of Africa's export on un-processed primary products is caused largely by the region's combination of low levels of education and abundant natural resources. An economic irony is that those countries blessed with abundant natural resources tend to grow more slowly than their resource-poor counterparts (Sachs, 2001).

Reliance upon oil and other commodities is deeply problematic for African nations wishing to avoid the typical 'resource curses' that tend to accompany overdependence on one particular commodity and/or to move beyond being suppliers of primary products. 'One risk is that even if there is a commodity boom, it might prevent governments from undertaking the necessary measures to make growth sustainable in the medium term (i.e., investment on human capital, infrastructure, institutional reform, etc.). Over-reliance on commodities such as oil threatens to make African nations even more vulnerable to negative price shocks. Furthermore, if receipts accrue from oil exports, there is a very real temptation from the local elites not to diversify their economies (Taylor, 2006). Moreover, natural resource endowment and currency overvaluation usually go together and this undermines the competitiveness of export-oriented manufacturing sectors.

However, this doesn't mean that natural resource abundance is always a curse. In fact, resource rich low income countries could diversify into resource based manufacturing or processing of primary commodities instead of following the conventional path of low skill manufacturing (Bonaglia and Fukasaku, 2003). For instance, Sweden and Finland at the beginning of $20^{\text {th }}$ century and Thailand and Malaysia very recently are good examples of how resource-rich countries could diversify into value-added agro-industries and resource-based manufacturing. Accordingly, Malaysia pursued the development of its resource-based sectors mainly palm oil and rubber; while Thailand focused on the diversification of agriculture and fishery-resource- based manufacturing, before both countries moving into other types of manufacturing exports such as clothing and electronics.

\section{xiv) Regional dummy}

It is also important to include a regional dummy variable in panel data analysis to capture other factors that are not included in the model on the dependent variable's outcome. Based on past experiences, the SSA 'dummy' variable is expected to have a negative relationship with export diversification.

To sum up, the above-mentioned determinants, their expected relationship with export diversification, and the respective data sources are summarized in Table 9. 
Table 9:- Independent variables, their expected signs and data sources

\begin{tabular}{|c|c|c|c|}
\hline Variable & Indicator & $\begin{array}{l}\text { Expected } \\
\text { sign }\end{array}$ & Data Sources \\
\hline Domestic Capital & Ratio of GFCF to GDP & + & WDI Database \\
\hline FDI & Ratio of net FDI to GDP & + & WDI Database \\
\hline \multirow[t]{2}{*}{ Human Capital } & $\begin{array}{l}\text { 1. Secondary School } \\
\text { Enrollment Ratio to total } \\
\text { population with age } 15 \\
\text { and above. }\end{array}$ & + & $\begin{array}{l}\text { Barro- Lee (2000); and WDI for some } \\
\text { countries and for years beyond } 2000 \\
\text { for all countries in the sample. }\end{array}$ \\
\hline & 2. Life Expectancy at Birth & + & WDI Database \\
\hline $\begin{array}{l}\text { Quality of } \\
\text { infrastructure }\end{array}$ & $\begin{array}{l}\text { Number of fixed and } \\
\text { mobile telephone per } 1000 \\
\text { person }\end{array}$ & + & WDI Database \\
\hline Inflation & $\begin{array}{l}\text { The rate of change of the } \\
\text { GDP deflator; }\end{array}$ & $-/+$ & WDI Database \\
\hline Exchange Rate & $\begin{array}{l}\text { Exchange rate of local } \\
\text { currency with that of US\$ }\end{array}$ & + & $\begin{array}{l}\text { Summer et al (2006) Penn World } \\
\text { Table Version } 6.2\end{array}$ \\
\hline Openness & $\begin{array}{l}\text { Degree of openness based } \\
\text { on Sachs and Warner } \\
\text { (1995) }\end{array}$ & + & $\begin{array}{l}\text { Summer et al (2006) Penn World } \\
\text { Table Version } 6.2\end{array}$ \\
\hline Income/capita & $\begin{array}{l}\text { Real per capita GDP (PPP } \\
\text { based) }\end{array}$ & + & IMF Database \\
\hline Political Instability & $\begin{array}{l}\text { Collier and Hoeffler's } \\
\text { (2004) 'War dummies' for } \\
\text { countries suffered from } \\
\text { war during the period } \\
\text { under study. }\end{array}$ & - & $\begin{array}{l}\text { Collier and Hoeffler (2004) war index } \\
\text { tables }\end{array}$ \\
\hline Aid per capita & $\begin{array}{l}\text { Official development } \\
\text { assistance/capita }\end{array}$ & $+/-$ & WDI Database \\
\hline Labor force & Size of population & + & $\begin{array}{l}\text { Summer et al (2006) Penn World } \\
\text { Table Version } 6.2\end{array}$ \\
\hline Resource & 1. Oil Dummies' & - & Various Statistics of each countries \\
\hline Endowment & 2. Arable Land Ratio & $+/-$ & WDI Database \\
\hline Regional Dummy & Africa dummy & - & \\
\hline
\end{tabular}

In line with this, list of countries included in this study are shown in Table 10. The selection criterion for the countries is mainly due to the availability of data from 1975-2004. 
Table 10:- Countries included in the study

\begin{tabular}{ll}
\hline Sub-Saharan Africa & East Asia \\
\hline Benin, Burkina-Faso, Burundi, Cameroon, Central Africa & China, Hong Kong, \\
Republic, Chad, Congo Democratic Republic, Congo & Indonesia, Japan, Korea \\
Republic, Cote Devoir, Ethiopia, Gabon, Gambia, Ghana, & Republic, Malaysia, \\
Kenya, Madagascar, Malawi, Mali, Mauritania, Mauritius, & Philippines, Singapore, \\
Mozambique, Niger, Nigeria, Rwanda, Senegal, & Taiwan, and Thailand. \\
Seychelles, Sierra Leone, South Africa, Sudan, & \\
Tanzania, Uganda, Zambia, and Zimbabwe & \\
\hline
\end{tabular}

\section{Research methodology and estimation methods measuring diversification}

There are quite few methods, which explain either export concentration (i.e. specialization) or diversification in a given time and space by a single indicator. The common measurement is the Herfindahl-Hirchmann Index $(\mathrm{HHI})$ which can be available from UNCTAD's Hand Book of Trade and Development Statistics, and is measured at the three-digit SITC level. Although this indicator is detailed enough, it doesn't capture the essence of both vertical and horizontal diversification (Agosin, 2005). Thus, considering the objective of examining the impacts of physical and human capital on vertical and horizontal export diversification, the following approach has been used like previous researchers.

\subsection{Vertical export diversification}

An increasing export orientation of the manufacturing sector, accompanied by a rising share of manufactures in total exports, is part of the "normal" pattern of structural change in the growth process of developing countries. Since vertical diversification (VDIV) mainly implies out of primary into manufactured exports, it can be measured by the share of manufactured exports to total exports [Elbadawi, 1999; Wood and Mayer, 2001; Munemo et al., 2007; Osakwe, 2007; and others]

$$
\operatorname{VDIV}=(\mathrm{TMX}) /(\mathrm{TX})
$$

Where, VDIV is the index of vertical diversification, TMX is value of total manufactured exports, and TX is value of total exports. 


\subsection{Horizontal export diversification}

Similar to the works of Herzer and Nowak-Lehmann (2006) as well as Feenstra and Kee (2004), horizontal diversification (HDIV) in this study has been proxied by the number of export commodities (varieties) classified by the Standard International Trade Classification (SITC) at the three-digit level. As Dennis and Shepherd (2007:5) noted, using a direct measure, namely a count of the number of products that a country exports is not as simple as it seems because individual "products" identified in the trade data usually map in reality to a number of distinct varieties. In other words, this simplified method can clearly measure how far a country has broadened the range of its products for export. Thus, the maximum value of the index is 239 , and its minimum (theoretical) value is zero, for a country with no exports. UNCTAD annually present the number of products, with those products that are greater than $\$ 100,000$ or more than 0.3 per cent of the country total exports.

\subsection{The basic econometric model for export diversification}

Based on the theoretical justifications made to identify determinants of export diversification that have been discussed earlier, and by following similar approaches such as: Osakwe (2007); Glyfason (2002); Bebczuky and Berrettoni (2006); Elbadawi (1999); Wood and Mayer (2001); Munemo (2007); Herzer and Nowak-Lehmann (2006); Parteka and Tamberi (2008); Elbadawi (1999), Agosin (2007), the econometric model that allows the explanatory variables explaining vertical and horizontal export diversification in a given country (i) at period $t$ takes the form:

VDIV $_{i t} /$ or HDIVit $=X_{i t} \beta+\varepsilon_{i t}$

Where $\beta$ is a vector of regression coefficients to be estimated; $X_{i t}$ is a matrix of explanatory variables displayed in Table 9; and $\varepsilon_{i t}$ is a vector of disturbances or random error terms. Accordingly, the simplified specification of this model will take the functional form:

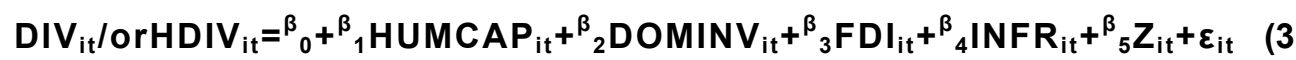

Where, $\alpha,{ }_{1}{ }_{1}{ }_{2}$ are constants, $i$ indexes the countries under study, $t$ denotes the year, while VDIV and HDIV refer the vertical and horizontal diversification indexes, respectively and they can be estimated one after the other; HUMCAP and DOMINV, FDI, and INFR are the measures of human capital stock, domestic capital, FDI, and infrastructure, respectively; and $Z_{\mathrm{it}}$ represents the set of additional explanatory variables as mentioned in Table 9 , and $\varepsilon_{i t}$ is the error term to account stochastic and measure. 
Additionally, there is a sensible presumption that investments on physical capital, human capital and other explanatory variables have mostly a delayed impact on diversification (Bebczuk and Berrettoni, 2006). In this case, explanatory variables with one-year lag values can be used in the model. The use of lagged explanatory variables has an additional advantage to deal with their potential endogeneity problems provided that future values of the export diversification index have no influence whatsoever on the control set. Thus, the export diversification model finally takes the form:

VDIV $_{\mathrm{it}} / \mathrm{HDIV}_{\mathrm{it}}={ }^{\beta}{ }_{0}+{ }_{1}^{\beta}$ HUMANCAP $_{\mathrm{it}-1}+{ }_{2}{ }_{2}$ DOMINV $_{\mathrm{it}-1}+{ }_{3}{ }_{3} \mathrm{FDI}_{\mathrm{it}-1}+{ }^{\beta}{ }_{4} \mathrm{NNFR}_{\mathrm{it}}+{ }_{5} \mathrm{Z}_{\mathrm{it}-1}+\varepsilon_{\mathrm{it}-1}$

In order to choose the more appropriate estimation techniques, it is first important to conduct specification tests including Hausmann specification test, test of heteroskedasticity, test for serial correlation, and stationarity test.

Accordingly, Hausmann's (1978) specification test was conducted and the result confirms fixed effect model estimation method is not appropriate for this particular study. Similarly, a White's General Test for heteroskedasticity was conducted and the result rejected the null hypothesis of homoskedasticity. Similarly, Wooldridge's tests for autocorrelation in panel data have been conducted and the null hypothesis that there is no first order autocorrelation was rejected. It implies that both heteroskedasticity and serial correlation are detected.

According to Wooldridge (2002), if heteroskedasticity is detected but serial correlation is not, then the usual heteroskedasticity-robust standard errors and test statistics from the pooled OLS regression can be used. However, if both heteroskedasticity and serial correlation are detected with a strict exogeneity assumption, it is reasonable to consider a Feasible General Least Square (FGLS) analysis. Likewise, Gujarati (2003) suggests that FGLS estimator accounts for a known structure of the error variance (heteroskedasticity), serial correlation pattern in the errors, or both, via a transformation of the original model.

Thus, FGLS estimator that accounts for a known structure of the error variance (heteroskedasticity), serial correlation pattern in the errors, via a transformation of the original model has been performed using STATA software. In line with this, 'Levin-Lin-Chu panel unit root test has been performed and the null-hypothesis of non-stationarity was rejected at 1 percent significance level. In other words, the data are stationary. For that matter, unit root test for panel data is a recent phenomenon and it was only practiced in pure time series data analysis until very recently (Baltagi, 1996). 


\section{Empirical results and main findings}

\subsection{Descriptive statistics}

\section{Summary statistics}

The mean values of the dependent and independent variables used in the analysis for the full sample have been displayed in Table 11. Accordingly, the average vertical diversification index as measured by the share of manufactured export to total export was found to be $26.8 \%$ with a sample range of 0 (minimum) and $100 \%$ (maximum). Similarly, the average horizontal diversification as measured by the number of export products in the SITC classification of international trade at three digits is 94 with a minimum range of 2 and a maximum range of 231. The ratio of GFCF to GDP has a mean value of $20 \%$ with a range of a $-24 \%$ (deficit) and $61 \%$ (maximum). The average value for the ratio of FDI to GDP is nearly $2 \%$ and ranges from $-29 \%$ (minimum) to $47 \%$ (maximum). The education component of human capital as measured by the secondary school enrollment ratio has an average value of about $18 \%$ that varies from $0.1 \%$ (minimum) to $62 \%$ (maximum), indicating the wide gap among countries with regard to investment on human capital. Likewise, the health component of human capital as measured by life expectancy at birth has a mean value of 54 years, but with a range of 36 years (minimum) and 82 years (maximum). In the same way; the mean, minimum, and maximum values of the remaining explanatory variables for the full sample are shown in Table 11.

Table 11: Descriptive statistics of variables for the full sample

\begin{tabular}{lrrrr}
\hline \multicolumn{1}{c}{ Variable } & Mean & Std. Dev. & Min & Max \\
\hline Vertical Diversification & 26.805 & 29.938 & 0 & 100 \\
Horizontal Diversification & 94.007 & 76.557 & 2 & 231 \\
Domestic Investment & 20.129 & 9.317 & -24 & 61 \\
Foreign Direct Investment & 1.995 & 4.064 & -29 & 46.7 \\
Education & 17.769 & 15.114 & 0.1 & 61.9 \\
Health (Life Expectancy) & 54.304 & 10.905 & 36 & 82 \\
Level of Development & 3.158 & 0.484 & 2.2618 & 4.471 \\
Population (log population) & 4.027 & 0.720 & 1.772 & 6.110 \\
Quality of Infrastructure & 0.987 & 0.846 & 0 & 3.241 \\
Degree of Openness & 72.946 & 61.287 & 0.85 & 425.34 \\
Inflation Rate & 49.247 & 31.941 & 11.88 & 371.85 \\
Oil Dummy & 0.146 & 0.354 & 0 & 1 \\
Arable land Ratio & 39.007 & 20.655 & 1 & 91 \\
Aid per capita & 8.787 & 10.223 & 0 & 99 \\
Exchange Rate & 1.532 & 1.848 & -11.777 & 4.376 \\
Political Instability & 0.293 & 0.455 & 0 & 1 \\
Africa Dummy & 0.146 & 0.354 & 0 & 1 \\
\hline
\end{tabular}


In order to examine the wide gap in East Asia and SSA's performances, it is much better to look the descriptive statistics of the sub-samples (SSA and East Asia) in depth as shown in Table 12. Accordingly, as measured at the mean, East Asia sub-sample exhibits a vertical diversification of $70 \%$ while SSA has a mean vertical diversification of nearly $15 \%$, verifies that East Asia has made a very significant and dynamic transformation on its economy towards manufacturing sector; whereas SSA has achieved very little in economic structural change and as a result the manufacturing exports from total exports in SSA accounts only $15 \%$ compared to $70 \%$ in East Asia. Again, the average number of export products in East Asia is found to be about 202 while in SSA, it is only about 64 , which implies that countries in SSA are still much dependent on the export of few commodities. The same is true regarding the ratio of gross fixed capital formation to GDP which is about $30 \%$ in East Asia while it is only $17 \%$ in SSA, which implies the low domestic savings and investments in SSA, while the opposite is true for East Asia. Another striking point is the secondary school enrollment ratio which is about $35 \%$ in East Asia, while it is only $13 \%$ in SSA.

Table 12: Descriptive statistics of variables for the Sub-Saharan Africa and East Asia

\begin{tabular}{|c|c|c|c|c|c|c|c|c|}
\hline \multirow{2}{*}{$\begin{array}{l}\text { Variable } \\
\text { Variable }\end{array}$} & \multicolumn{4}{|c|}{ Sub-Saharan Africa } & \multicolumn{4}{|c|}{ East Asia } \\
\hline & Mean & $\begin{array}{l}\text { Std. } \\
\text { Dev. }\end{array}$ & Min & Max & Mean & $\begin{array}{l}\text { Std. } \\
\text { Dev. }\end{array}$ & Min & Max \\
\hline $\begin{array}{l}\text { Vertical } \\
\text { Diversification }\end{array}$ & 14.633 & 15.936 & 0 & 81 & 70.081 & 27.946 & 2 & 100 \\
\hline $\begin{array}{l}\text { Horizontal } \\
\text { Diversification }\end{array}$ & 63.734 & 54.402 & 2 & 256 & 201.641 & 36.436 & 86 & 235 \\
\hline $\begin{array}{l}\text { Domestic } \\
\text { Investment }\end{array}$ & 17.421 & 8.186 & -24 & 61 & 29.757 & 6.201 & 16 & 48 \\
\hline $\begin{array}{l}\text { Foreign Direct } \\
\text { Investment }\end{array}$ & 1.464 & 3.5628 & -29 & 46.7 & 3.883 & 5.063 & -3 & 37.1 \\
\hline Education & 13.075 & 11.739 & 1 & 57 & 34.458 & 13.936 & 6.9 & 61.9 \\
\hline Life Expectancy & 49.938 & 7.291 & 36 & 73 & 69.83 & 6.617 & 47 & 82 \\
\hline $\begin{array}{l}\text { Level of } \\
\text { Development }\end{array}$ & 3.013 & 0.370 & 2.262 & 4.249 & 3.671 & 0.490 & 2.302 & 4.471 \\
\hline $\begin{array}{l}\text { Population (log } \\
\text { population) }\end{array}$ & 3.847 & 0.6027 & 1.772 & 5.127 & 4.665 & 0.740 & 3.348 & 6.11 \\
\hline $\begin{array}{l}\text { Quality of } \\
\text { Infrastructure }\end{array}$ & .727 & .6395 & 0 & 2.956 & 1.911 & 0.847 & 0.301 & 3.241 \\
\hline $\begin{array}{l}\text { Degree of } \\
\text { Openness }\end{array}$ & 61.201 & 31.534 & 0.85 & 209.34 & 114.706 & 106.644 & 9.6 & 425.34 \\
\hline Inflation Rate & 48.015 & 31.367 & 11.88 & 371.85 & 53.628 & 33.597 & 12.12 & 193.8 \\
\hline Oil Dummy & 0.156 & 0.363 & 0 & 1 & 0.111 & 0.315 & 0 & 1 \\
\hline Arable Land Ratio & 43.160 & 19.999 & 8 & 91 & 24.237 & 15.575 & 1 & 60 \\
\hline Aid Per Capita & 11.119 & 10.441 & 0 & 99 & 0.496 & 0.678 & 0 & 3 \\
\hline Exchange Rate & 1.551 & 2.017 & -1.777 & 4.376 & 1.461 & 1.043 & .149 & 4.011 \\
\hline Political Instability & .313 & .464 & 0 & 1 & 0.222 & 0.417 & 0 & 1 \\
\hline
\end{tabular}


This again indicates how East Asia remarkably invested on education; whereas SSA's investment on education has been found to be very minimal. Likewise, the mean life expectancy at birth in SSA is estimated to be about 50 years, whereas it is about 70 years in East Asia. This implies that East Asia's performance both in education and health aspects of human capital has been extremely impressive while the opposite was true for SSA's performance in human capital formation for the last three decades. By the same token, the mean arable land ratio to total land is about $43 \%$ in SSA; while it was only about $24 \%$ in East Asia. This highlights SSA has a large natural resource endowment in arable land that would have been utilized for more agricultural production and related sectors. The same comparison for all variables confirms the huge gap that exists between the performances of the two regions (Table 12).

Figures 4, 5, 6, and 7 demonstrate the divergence performance of East Asia and SSA countries between 1975 and 2004, related to vertical and horizontal diversification, MVAD and income per capita, respectively. It is therefore evident that except South Africa and Mauritius in SSA, all other countries have achieved very little in increasing either their income per capita or MVAD from 1975-2004. By the same token; though SSA's performance to diversify horizontally is better off compared with the vertical ones, and yet a lot has remained to catch-up with East Asia.

Figure 4: Vertical export diversification in Sub-Saharan Africa and East Asia (1975-2004)

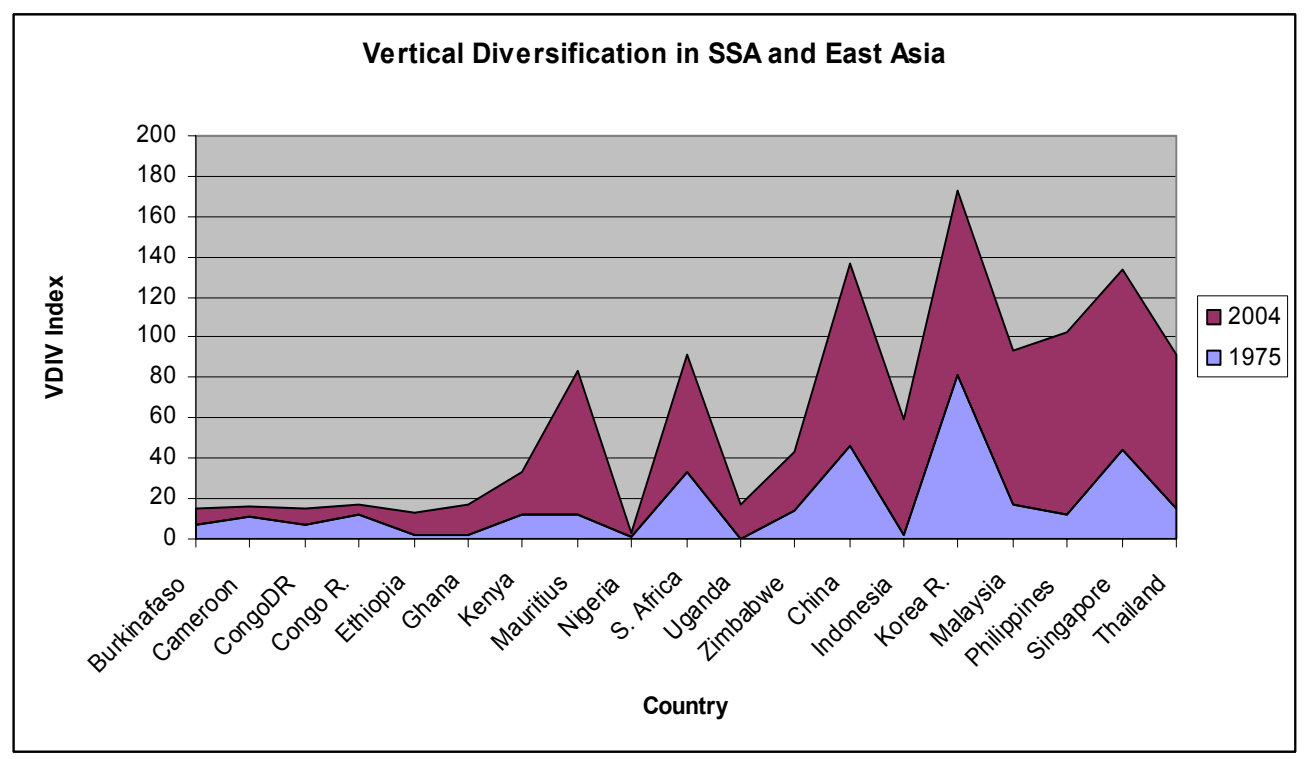


Figure 5: Horizontal export diversification in Sub-Saharan Africa and East Asia (1975-2004)

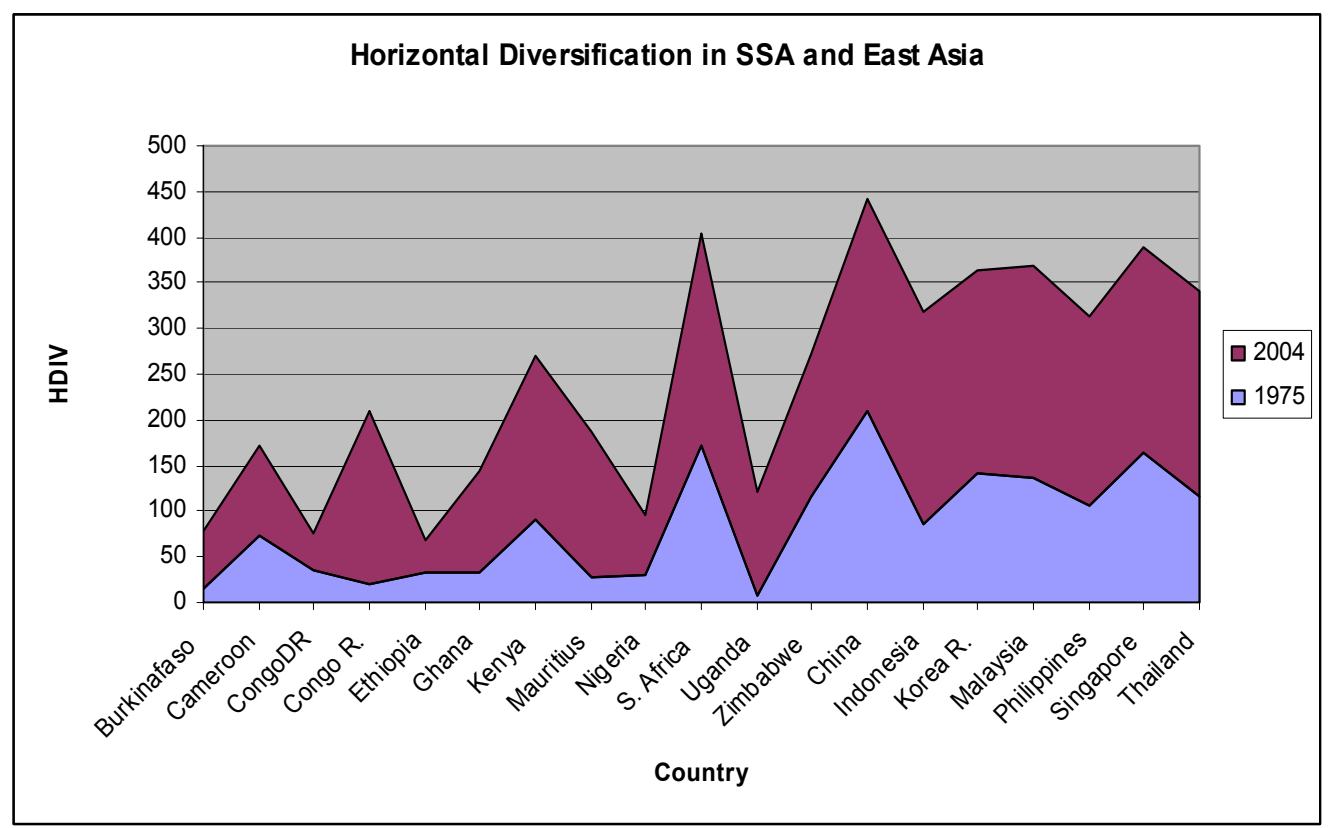

Figure 6: Manufacturing value added in sub-Saharan Africa and East Asia (1975-2004)

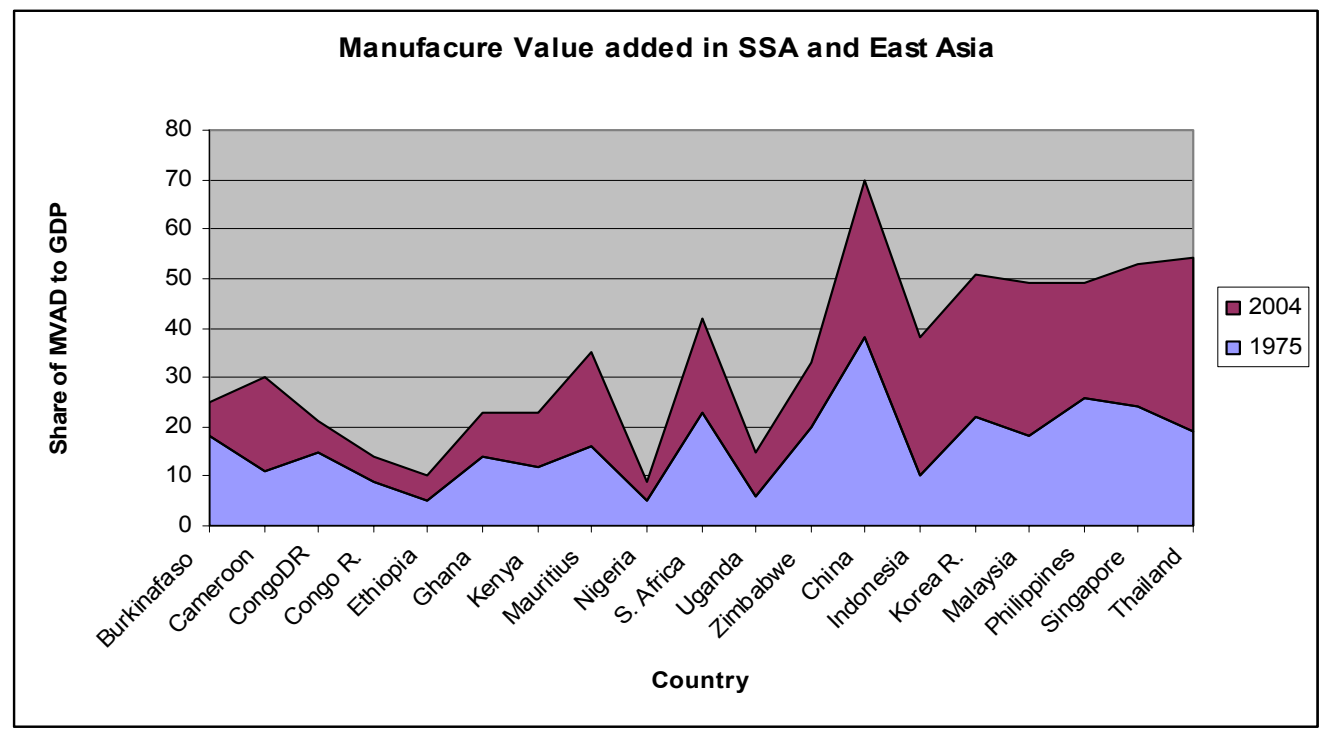


Figure 7: Income per capita in sub-Saharan Africa and East Asia (1975-2004)

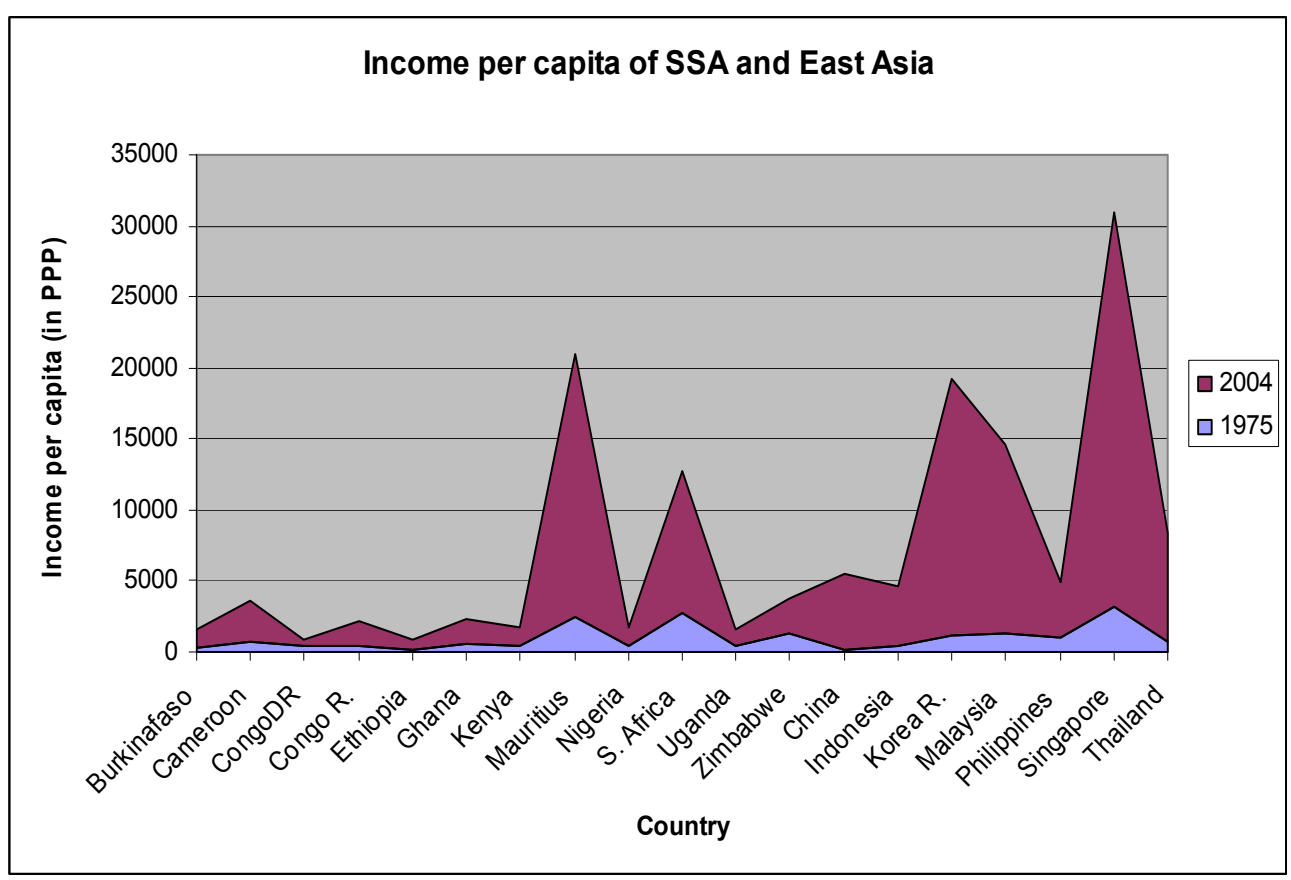

\section{Partial correlations}

The correlation coefficients of vertical export diversification as well as horizontal export diversification with all independent variables have been estimated and shown in Table 13. Hence, it has been evident that FDI, education, income per capita, population size, degree of openness, depreciating exchange rate are all positively and significantly correlated with vertical as well as horizontal export diversification. Quality of infrastructure and oil dummy variables have been found to be positively and negatively correlated with vertical diversification, respectively. On the other hand, arable land ratio and aid per capita are both found to be positively and significantly correlated with horizontal export diversification. 
Table 13: Partial correlation of VDIV and HDIV with the independent variables

\begin{tabular}{lrrrr}
\hline \multirow{2}{*}{ Variable } & \multicolumn{2}{c}{ VDIV } & \multicolumn{2}{c}{ HDIV } \\
\cline { 2 - 5 } & \multicolumn{1}{c}{ Corr. } & \multicolumn{1}{c}{ Sig. } & \multicolumn{1}{c}{ Corr. } & \multicolumn{1}{c}{ Sig. } \\
\hline Domestic Investment & 0.0423 & 0.141 & 0.0238 & 0.408 \\
Foreign Direct Investment & 0.0722 & $0.012^{* *}$ & 0.0915 & $0.001^{* * *}$ \\
Education & 0.0687 & $0.017^{* *}$ & 0.1651 & $0.000^{* * *}$ \\
Life Expectancy & 0.0435 & 0.129 & 0.0440 & 0.126 \\
Income per capita & 0.1936 & $0.000^{* * *}$ & 0.2650 & $0.000^{\star * *}$ \\
Population (log population) & 0.2033 & $0.000^{* * *}$ & 0.5681 & $0.000^{* * *}$ \\
Quality of Infrastructure & 0.1214 & $0.000^{* * *}$ & 0.0030 & 0.917 \\
Degree of Openness & 0.0598 & $0.037^{* *}$ & 0.3221 & $0.000^{* * *}$ \\
Inflation Rate & 0.0309 & 0.282 & 0.0268 & 0.350 \\
Oil Dummy & -0.2995 & $0.000^{* * *}$ & -0.0179 & 0.533 \\
Arable Land Ratio & -0.0368 & 0.1999 & 0.1453 & $0.000^{* * *}$ \\
Aid Per Capita & 0.0228 & 0.427 & -0.0835 & $0.004^{* * *}$ \\
Exchange Rate & 0.0867 & $0.002^{* * *}$ & 0.0861 & $0.003^{* * *}$ \\
Political Instability & -0.0299 & 0.297 & -0.2158 & $0.000^{* * *}$ \\
Africa Dummy & -0.2961 & $0.000^{* * *}$ & -0.1482 & $0.000^{\star * *}$ \\
\hline Note: & & & &
\end{tabular}

\section{Note:}

* refers statistically significance at $10 \%$ level.

** refers statistically significance at $5 \%$ level.

${ }^{* * *}$ refers statistically significance at $1 \%$ level.

Moreover, an attempt has been made to examine the relationship between income per capita and export diversification (both vertical and horizontal) so as to test the validity of Imbs and Wacziarg (2003) hypothesis, based on the evidence from four low income SSA countries (Ethiopia, and Ghana), two developing economies from East Asia (China and Thailand), A fully developed economy (Japan).

Accordingly, Figure 8-12 below demonstrate that income per capita and export diversification especially horizontal export diversifications are all increasing in the four SSA countries. Likewise, income per capita, vertical and horizontal export diversification have become increasing in emerging economies of China and Thailand. However, the evidence from Japan confirms the relationship between income per capita and export diversification had been positive until it was fully developed and then it is on decline. Therefore, this verifies the validity of Imbs and Wacziarg (2003) hypothesis that export diversification increases as income per capita increases mostly in developing countries; whereas for developed countries, the economy will start to re-concentrate on specialized products and services as it has been evident from Japan's experience. 
Figure 8: Trend of export diversification and income/capita in China

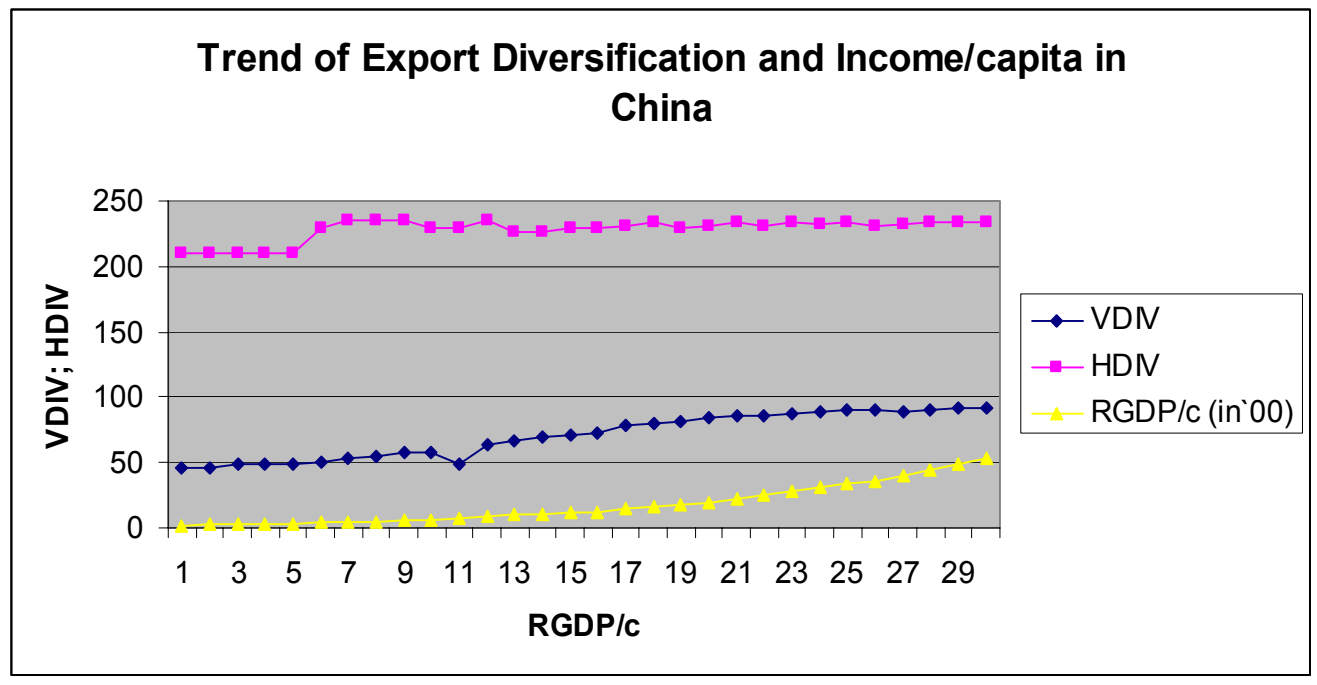

Figure 9: Trend of export diversification and income/capita in Thailand

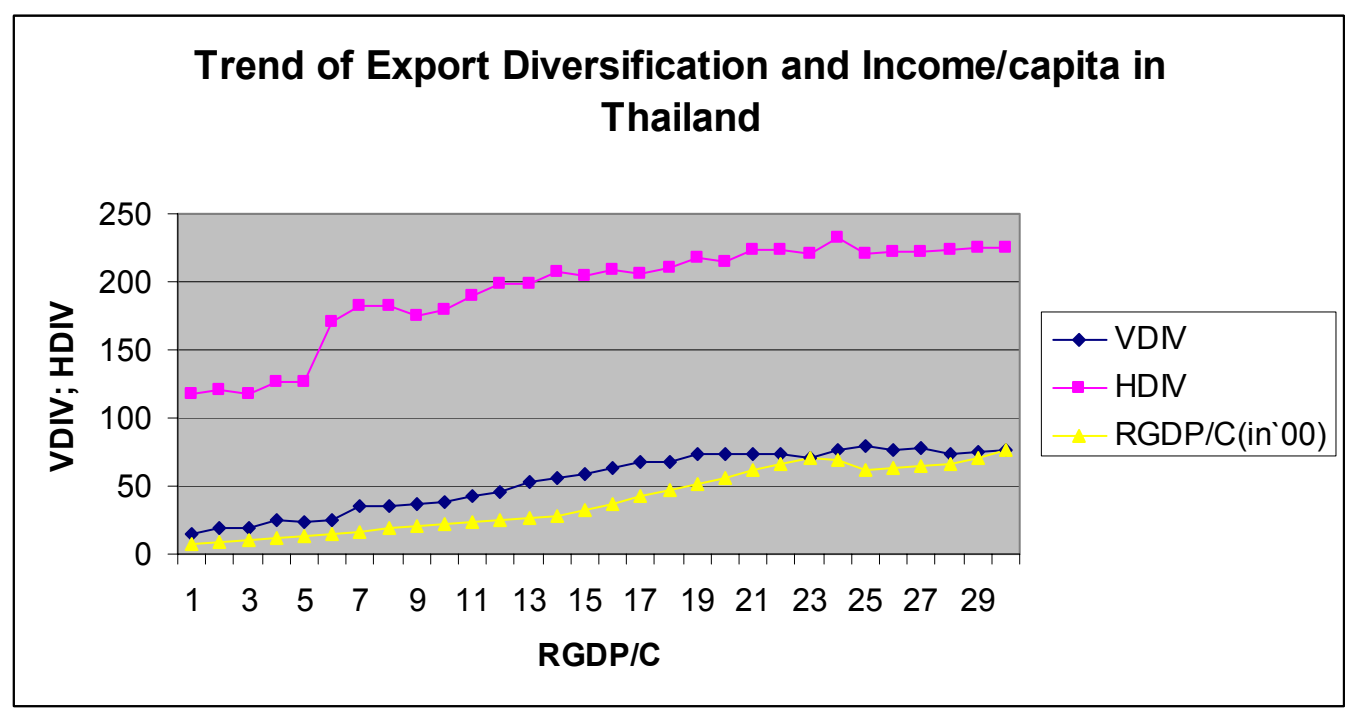


Figure 10: Trend of export diversification and income/capita in Japan

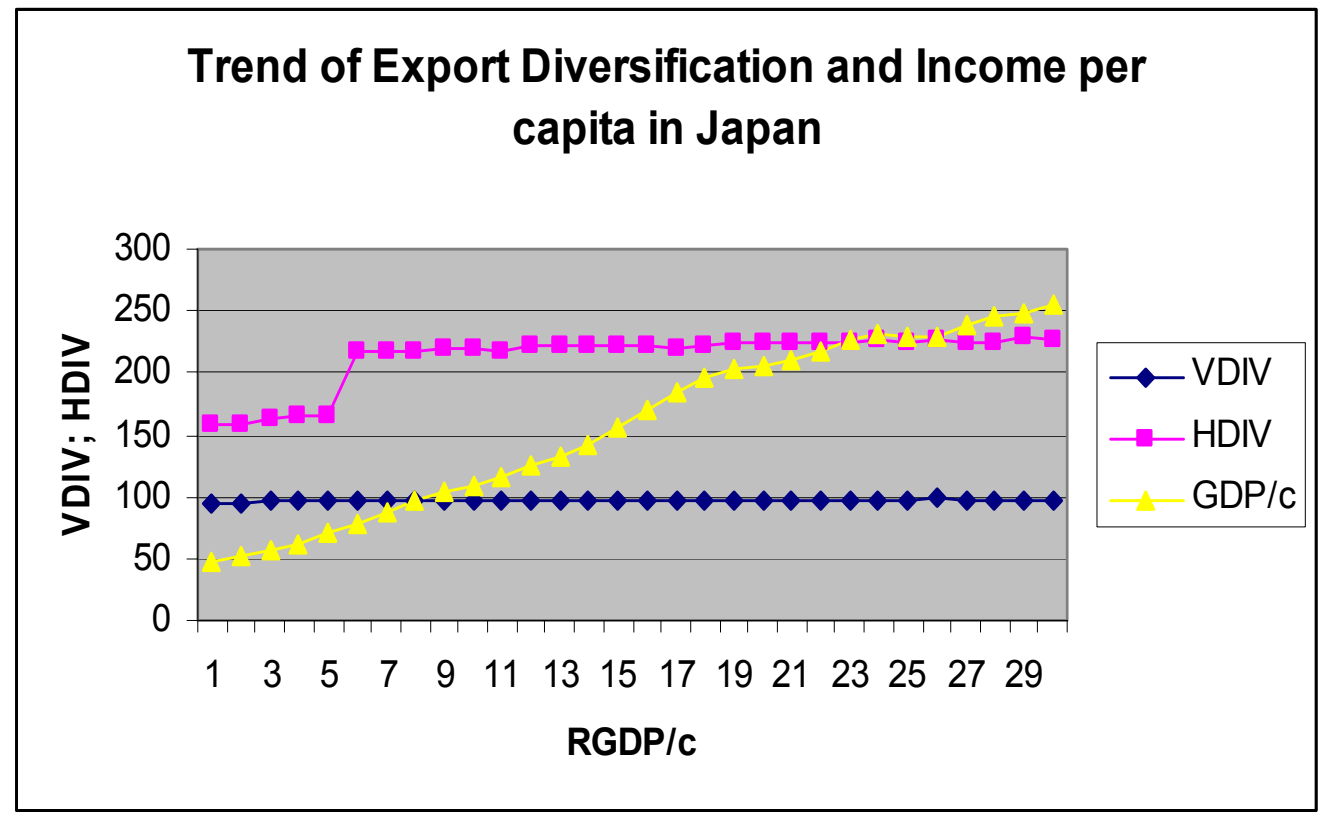

Figure 11: Trend of export diversification and income/capita in Ethiopia

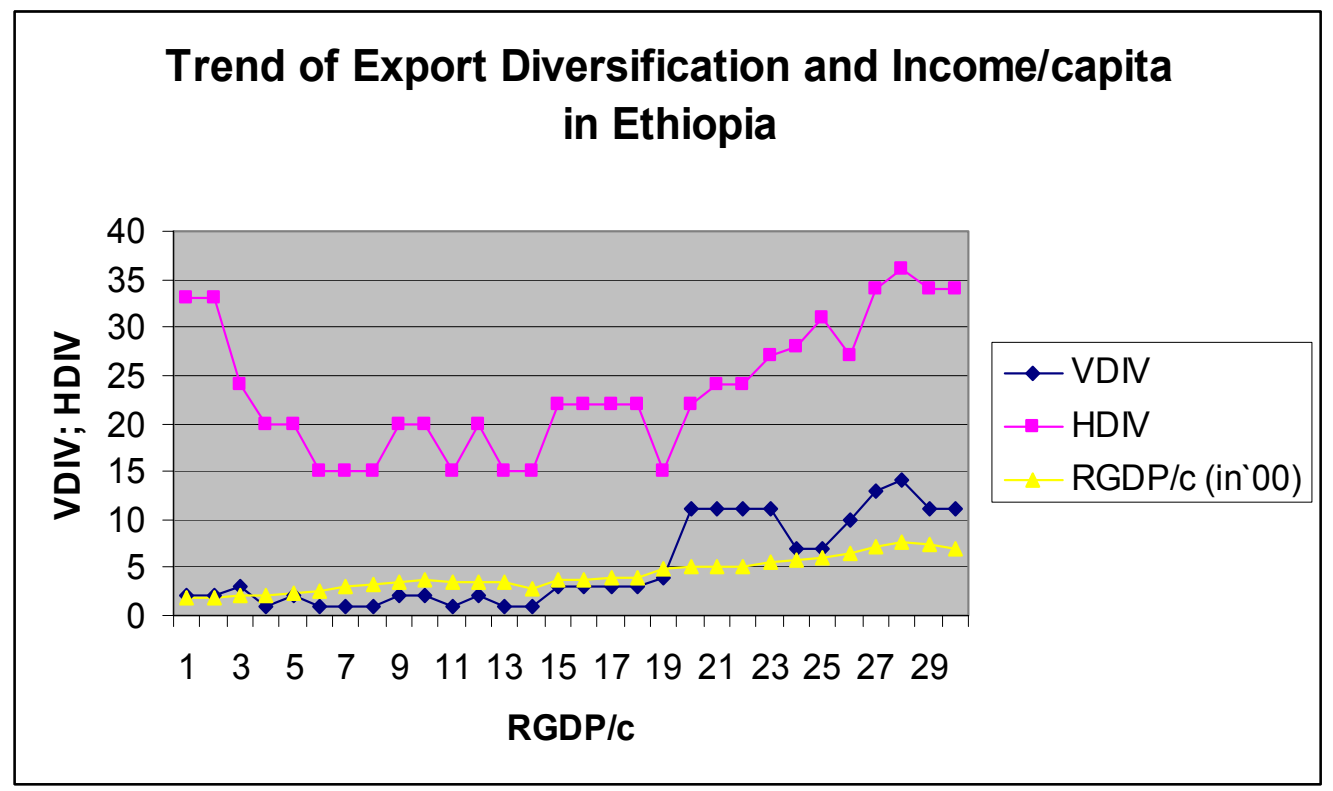


Figure 12: Trend of export diversification and income/capita in Ghana

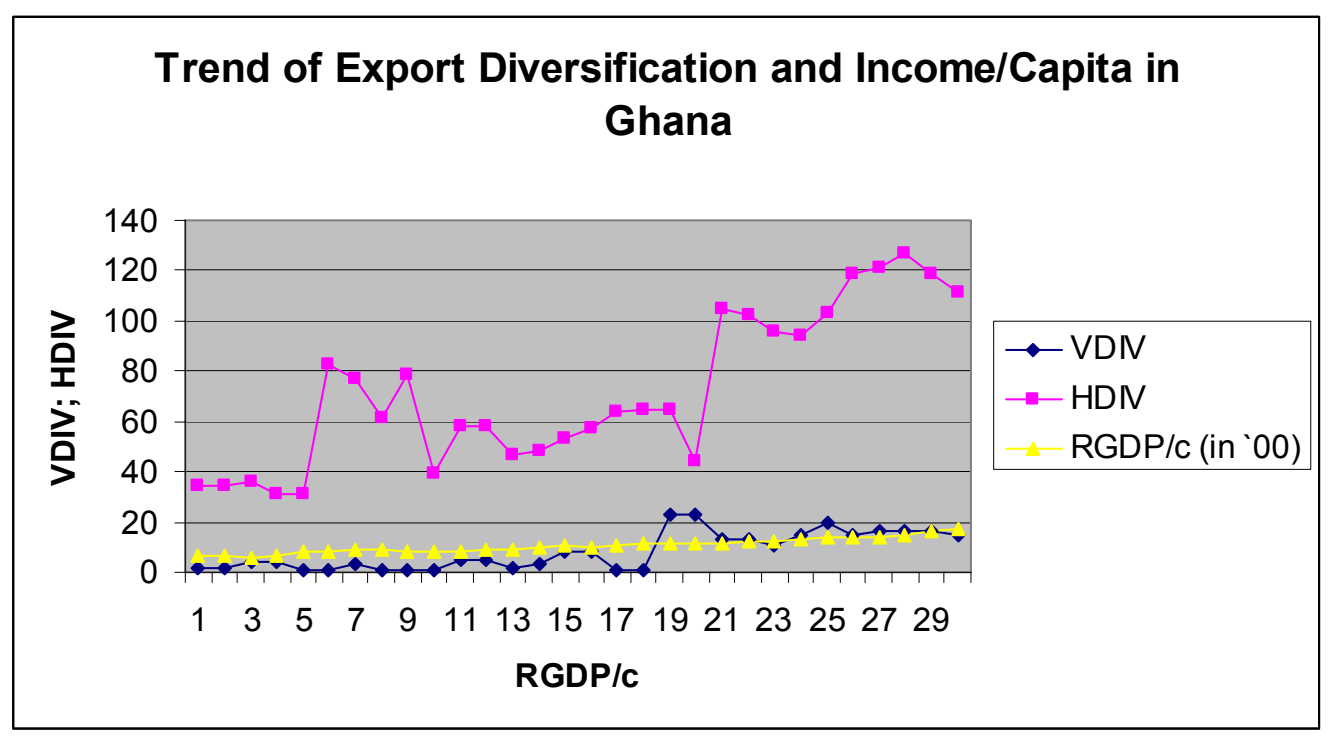

\section{Regression results and main findings}

The empirical results from the full sample (Table 14) confirm FDI, education, life expectancy, income per capita, population size, infrastructure, openness, arable land ratio, depreciating exchange rate are the most significant and positive determinants to induce vertical as well as horizontal export diversification. On the other hand, it was evident that 'oil dummy' and 'Africa dummy' have been found to be negatively and significantly affecting vertical as well as horizontal export diversification for the full sample. Likewise, it has been found that domestic investment and political instability are positive and negative determinants for horizontal export diversification, respectively. The 'Africa Dummy' which is a proxy to capture regional differences as a result of factors which are not included in model has been found to be a negative and significant determinant to affect vertical as well as horizontal export diversification in SSA. 
Table 14: Cross-sectional time-series FGLS regression results for all countries

\begin{tabular}{|c|c|c|}
\hline Variables & Vertical Diversification & Horizontal Diversification \\
\hline Domestic Investment & $\begin{array}{c}.0056 \\
(.0062)\end{array}$ & $\begin{array}{l}.0541^{\star \star \star} \\
(.0132)\end{array}$ \\
\hline Foreign Direct Investment & $\begin{array}{l}.0653^{* * *} \\
(.0114)\end{array}$ & $\begin{array}{l}.0512^{*} \\
(.0288)\end{array}$ \\
\hline Education & $\begin{array}{l}.1830^{\star * *} \\
(.0210)\end{array}$ & $\begin{array}{l}.1405^{\star *} \\
(.0691)\end{array}$ \\
\hline Life Expectancy & $\begin{array}{l}.0779 * * * \\
(.0136)\end{array}$ & $\begin{array}{l}.1923^{\star \star \star} \\
(.0419)\end{array}$ \\
\hline Income per Capita & $\begin{array}{c}17.129^{* * *} \\
(.7423)\end{array}$ & $\begin{array}{c}51.169^{* * *} \\
(2.0465)\end{array}$ \\
\hline Population & $\begin{array}{c}3.7947^{* * *} \\
(.8918)\end{array}$ & $\begin{array}{c}47.381^{* * *} \\
(1.3612)\end{array}$ \\
\hline Quality of Infrastructure & $\begin{array}{c}3.3884^{* * *} \\
(.3811)\end{array}$ & $\begin{array}{c}2.758^{* * *} \\
(.9653)\end{array}$ \\
\hline Degree of Openness & $\begin{array}{l}.024^{\star * *} \\
(.0026)\end{array}$ & $\begin{array}{l}.1554^{\star \star *} \\
(.0097)\end{array}$ \\
\hline Inflation Rate & $\begin{array}{c}-0.0039 \\
(.0020\end{array}$ & $\begin{array}{c}.0699 * * * \\
(.0115)\end{array}$ \\
\hline Oil Dummy & $\begin{array}{l}-9.472^{\star \star \star} \\
(1.1775)\end{array}$ & $\begin{array}{c}-18.0729^{* * *} \\
(2.0405)\end{array}$ \\
\hline Arable Land Ratio & $\begin{array}{c}0.1028^{* * *} \\
(0.169)\end{array}$ & $\begin{array}{l}.0843^{* \star} \\
(.0397)\end{array}$ \\
\hline Aid per capita & $\begin{array}{l}.0160^{* * *} \\
(.0050)\end{array}$ & $\begin{array}{l}-.0296 \\
(.0153)\end{array}$ \\
\hline Exchange Rate & $\begin{array}{c}0.9223^{* * *} \\
(.1245)\end{array}$ & $\begin{array}{c}2.7667^{* \star *} \\
(.2605)\end{array}$ \\
\hline Political Instability & $\begin{array}{l}-1.9465 \\
(1.3912)\end{array}$ & $\begin{array}{c}-21.484^{* * *} \\
(1.3766)\end{array}$ \\
\hline Africa Dummy & $\begin{array}{c}-10.0032^{* * *} \\
(2.1707)\end{array}$ & $\begin{array}{c}-41.7382^{* * *} \\
(3.9299)\end{array}$ \\
\hline Constant & $\begin{array}{c}-54.007^{\star \star *} \\
(5.1672)\end{array}$ & $\begin{array}{c}-236.0684^{\star * *} \\
(11.6148)\end{array}$ \\
\hline No. of Observation & 1230 & 1230 \\
\hline No. of Groups & 41 & 41 \\
\hline Time periods & 30 & 30 \\
\hline Wald Chi2 (14) & 1621.62 & 10269.66 \\
\hline
\end{tabular}

\section{Note:-}

* refers statistically significance at $10 \%$ level.

** refers statistically significance at $5 \%$ level.

${ }^{* * *}$ refers statistically significance at $1 \%$ level. 
The robustness of the above results as well as the implications for each finding is investigated along with the findings from the sub-samples analysis (Table 15). Accordingly, the evidence from the sub-samples analysis revealed that, domestic investment plays an important role to induce vertical as well as horizontal export diversification in the case of East Asia, while it plays a significant role only to promote horizontal diversification in the case of SSA. The reason might be the fact that domestic capital formation which is mainly driven by domestic savings are still at lower stage in many SSA countries and hence its contribution to enhance vertical diversification and exporting high value-added manufactured exports is insignificant. On the contrary, the evidence confirms East Asian countries have been successful in domestic capital formation mainly through domestic savings and this in turn significantly contributed for promoting vertical as well as horizontal export diversification. By the same token, FDI has been found to be positively and significantly affecting vertical and horizontal export diversification in East Asia; but it only induces vertical diversification in the case of SSA; verifying one of the research hypotheses that FDI in SSA is still under the threshold level and its contribution to export diversification wouldn't be as satisfactory as compared to East Asia. Additional explanation why the outcomes of FDI to be different in the two regions may be the fact that educational level, development of local financial markets, and other local conditions are not adequate enough to attract FDI and play a positive role and materialize vertical export diversification in SSA. Thus, the implication is that SSA countries have to make a strong effort not only in creating a conducive atmosphere to motivate domestic capital accumulation, but also a wide range of activities should be made in attracting foreign capital to be used as alternative sources of capital formation and thereby for vertical as well as horizontal export diversification.

By the same token, the educations as well as the health components of human capital have been found to be highly significant determinants for promoting vertical and horizontal diversification in East Asia, implying again countries in this region have significantly invested on education and health care system. On the other hand, the evidence from SSA sub-sample analysis has confirmed the education factor was very important to enhance both vertical and horizontal diversification, but the health variable has been a significant factor only for promoting vertical diversification in SSA. Again, this implies that SSA has to do more in investment on education as well as health so as to achieve a radical change on its economy, specifically to achieve a significant change in vertical and horizontal export diversification as it has been witnessed in East Asia. 
Table 15: Comparison of Sub-Saharan Africa and East Asia countries

\begin{tabular}{|c|c|c|c|c|}
\hline \multirow[t]{2}{*}{ Variables } & \multicolumn{2}{|c|}{ Vertical Diversification } & \multicolumn{2}{|c|}{ Horizontal Diversification } \\
\hline & SSA & East Asia & SSA & East Asia \\
\hline \multirow{2}{*}{ Ratio of GFCF to GDP } & .0056 & $0882^{*}$ & $.0236^{\star * *}$ & $.2146^{* *}$ \\
\hline & $(.0047)$ & $(.0498)$ & $(.0059)$ & $(.1103)$ \\
\hline \multirow{2}{*}{ Ratio of FDI to GDP } & $.0593^{\star * *}$ & $1431^{* *}$ & .1411 & $.1201^{* * *}$ \\
\hline & $(.0093)$ & $(.0646)$ & $(.1074)$ & $(.0098)$ \\
\hline \multirow{2}{*}{ Education } & $.0582^{\star * *}$ & $646^{* * *}$ & $.2715^{\star \star *}$ & $.464^{\star \star *}$ \\
\hline & $(.0208)$ & $(.0768)$ & $(.0372)$ & $(.1499)$ \\
\hline \multirow{2}{*}{ Life Expectancy } & $.0581^{* * *}$ & $2751^{* *}$ & .1604 & $.2001^{* * *}$ \\
\hline & $(.012)$ & $(.1376)$ & $(.2899)$ & $(.023)$ \\
\hline \multirow{2}{*}{ Income per Capita } & $13.838^{* * *}$ & $13.352^{* * *}$ & $53.1515^{\star * *}$ & $39.833^{* * *}$ \\
\hline & $(.6698)$ & $(2.5383)$ & $(.9725)$ & $(8.829)$ \\
\hline \multirow{2}{*}{ Population } & $2.8721^{* * *}$ & $8.1605^{* * *}$ & $55.7658^{* * *}$ & $15.123^{* * *}$ \\
\hline & $(.5868)$ & $(2.8984)$ & $(1.0122)$ & $(4.8256)$ \\
\hline \multirow{2}{*}{ Quality of Infrastructure } & $2.5586^{* * *}$ & $2.5873^{* * *}$ & $7.9446^{* * *}$ & $4.2215^{\star *}$ \\
\hline & $(.2999)$ & $(1.3180)$ & $(.5389)$ & $(2.5154)$ \\
\hline \multirow{2}{*}{ Degree of Openness } & $.0086^{* * *}$ & $0508^{* * *}$ & $.1823^{* * *}$ & $.0768^{* * *}$ \\
\hline & $(.0025)$ & $(.0139)$ & $(.0039)$ & $(.0227)$ \\
\hline \multirow{2}{*}{ Inflation Rate } & $-.0041^{*}$ & .0041 & $.1143^{* * *}$ & $-.0622^{* *}$ \\
\hline & $(.0022)$ & $(.0143)$ & $(.0052)$ & $(.0304)$ \\
\hline \multirow{2}{*}{ Oil Dummy } & $-6.6847^{* * *}$ & $-44.8368^{* * *}$ & $-15.3397^{* * *}$ & $-24.838^{* * *}$ \\
\hline & $(.5004)$ & $(5.6653)$ & $(.8530)$ & (9.2097) \\
\hline \multirow{2}{*}{ Arable Land ratio } & $1539^{* * *}$ & $.2019^{* *}$ & $.1163^{\star * *}$ & $7314^{\star \star *}$ \\
\hline & $(.0177)$ & $(.0879)$ & $(.0182)$ & $(.2396)$ \\
\hline \multirow{2}{*}{ Aid per capita } & $0322^{* * *}$ & $1.637^{* * *}$ & $-.0357^{* * *}$ & 7305 \\
\hline & $(.0038)$ & $(.5293)$ & $(.0083)$ & $(1.0766)$ \\
\hline \multirow{2}{*}{ Exchange Rate } & $2471^{* * *}$ & $11.6265^{\star * *}$ & $2.5855^{\star * *}$ & $-3.6277^{*}$ \\
\hline & $(.0502)$ & (1.4578) & $(.1548)$ & $(1.9314)$ \\
\hline \multirow{2}{*}{ Political Instability } & $-4.8529^{\star \star *}$ & -.5743 & $-15.711^{* * *}$ & $-27.4911^{\star * *}$ \\
\hline & $(.7379)$ & (3.5833) & $(1.2452)$ & $(6.5411)$ \\
\hline \multirow{2}{*}{ Constant } & $-45.5182^{* \star *}$ & $-88.449^{* * *}$ & $-326.1033^{* *}$ & $-57.77^{\star}$ \\
\hline & (3.5547) & $(16.4292)$ & (5.498) & (35.773) \\
\hline No. of Observation & 960 & 270 & 960 & 270 \\
\hline No. of Groups & 32 & 9 & 32 & 9 \\
\hline Time periods & 30 & 30 & 30 & 30 \\
\hline Wald Chi2 (13) & 3065.74 & 3254.07 & 12367.85 & 201.03 \\
\hline
\end{tabular}

Note:

* refers statistically significance at $10 \%$ level.

** refers statistically significance at $5 \%$ level.

${ }^{* \star *}$ refers statistically significance at $1 \%$ level. 
Although the standard results of the main determinants are fairly robust for both Sub-Saharan Africa and East Asia, the magnitudes of coefficients vary across the two regions. The effects of human capital, domestic capital, and FDI both on vertical as well as horizontal export diversification have been highest in East Asia and less in Sub-Saharan Africa sub-sample, implying a similar ranking of investment in human capital and the marginal product of capital in the two regions. For instance, the estimated elasticity of education and health components of human capital for vertical diversification in East Asia was found to be 0.646 and 0.2751 , respectively; while they were only 0.0582 and 0.0581 for SSA sub-samples, respectively. In the same token, the elasticity of education and health for horizontal diversification in East Asia were found to be 0.464 and 0.2001 , respectively; while for SSA were only 0.2715 and 0.1604 , respectively. The same is true for the elasticity's of FDI and domestic capital with regard to their effects on vertical as well as horizontal export diversification in the two regions as shown in Table 15. Thus, the East Asian experience shows that domestic physical capital, investment on human capital and FDI are complements not substitutes with each other, and all positively and significantly contribute to both vertical as well as horizontal export diversification.

Income per capita which is a proxy for level of development has been found to be statistically significant at $1 \%$ level for both SSA as well as East Asia. This is again consistent both in the full-sample as well as in the sub-samples analyses that verified the research hypotheses proposed earlier that income per capita and export diversification have a positive relationship mainly in developing countries. In fact, the elasticity's of this variable is high in the case of SSA rather than East Asia, perhaps in line with the arguments by Imbs and Wacziarg (2003) that diversification initially increases as per capita incomes increases and then it becomes decreasing. In other words, though most of the East Asian countries in the sample except Japan are still classified as developing countries, most of them have achieved high income per capita and hence it is expected that the rate of increase in export diversification to become less and less.

As expected, 'degree of openness' has been found to be an important and statistically significant factor for export diversification both in the full sample and sub-samples analyses, implying a step-by step liberalization and opening the economy is one of the pre-requisites in order to enhance vertical as well as horizontal export diversification. In line with this, 'infrastructure' is also positively associated with vertical and horizontal diversification and the result is also consistent both in the full-sample analysis as well as the sub-samples analyses. Thus, the results support the widely held view that the quality of infrastructure and openness to foreign markets are critical to diversification. Furthermore, population size has been found to be significant and positive 
determinants for both vertical and horizontal diversification in the full sample as well as in the sub-sample analyses; implying domestic demand is one of the driving factors for a country to diversify both vertically and horizontally. This is also in line with the proposition of 'endogenous growth theory' that countries can benefit from larger scale such that with a larger population and a larger market size. In other words, countries are expected to grow faster because of scale economies.

Inflation has a mixed effect on vertical and horizontal diversification both in the full-sample as well as the sub-samples. For instance, inflation is negatively associated with vertical diversification; but positively associated with horizontal diversification in the analysis of the full sample (Table13). However, the sub-sample analysis in Table 14, confirms that inflation is negatively correlated in SSA's vertical export diversification and East Asia's horizontal diversification. On the other hand, the evidence shows inflation has a positive significant effect on SSA's horizontal export diversification. Generally, the results are not conclusive and the intuition is that moderate level of inflation can be sometimes associated with economic growth. For that matter, a low and single-digit level of inflation doesn't have a negative effect on either export diversification in particular or to economic growth in general. However, it should be noted that high levels of inflation damage diversification prospects and the tendency under such circumstances is for increased concentration with little opening-up to new export sectors.

Similar to pervious works by others, natural resource endowment proxied by oil resource has a negative and significant effect on both vertical and horizontal export diversification for the full sample as well as the sub-samples. However, natural resources endowment proxoed by 'arable land ratio' has been found to be an important positive determinant to enhance vertical and horizontal export diversification both for the full-sample as well as the sub-samples. The results therefore don't support the generalized view, that resource abundance can have a negative effect on diversification as well as growth. Therefore, SSA has a relatively large proportion of arable land compared to East Asia and this would be an advantage to diversify not only horizontally, but also vertically towards value-added agro-industries and related manufacturing sector through utilizing its abundant agricultural raw materials.

Likewise, it is not surprising to find political instability to be a negative and statistically significant factor for the full sample as well as the sub-samples analyses; since a more stable and durable political regime is vital to improve the prospects for successful diversification in any country. Interestingly, this variable has become significant at $1 \%$ level and negatively affects vertical and horizontal diversification for SSA sub-sample; where as it negatively affects only horizontal diversification in East Asia. In other words, there is no indication that political instability has a significant effect on vertical diversification for East Asia sub-sample. This was because of countries in East Asia 
are not this much suffered from political instability for the last three decades, and this makes the 'war dummy' variable to be statistically insignificant factor to explain vertical export diversification, which is the dominant type of export diversification in East Asia. Conversely, Sub-Saharan Africa has tremendously suffered from the consequences of prolonged war for the last three decades and it is not surprising to find out a very significant and negative relationship between political instability and vertical and horizontal export diversification for SSA sub-sample.

Foreign aid has been found to be statistically significant at $1 \%$ level and positively affecting vertical diversification; but statistically insignificant for horizontal diversification for the full sample analysis. A detailed analysis for the sub-samples shows that foreign aid has still a positive and significant effect on vertical export diversification both in SSA and East Asia, but it is negatively affecting horizontal diversification in SSA. The empirical results, therefore, indicate that unlike previous assumptions, foreign aid can't always have an anti-export bias due to a 'Dutch disease' effect by causing an appreciation of the real exchange rate. In fact, the results indicate that if properly managed, foreign aid can play a positive role in promoting vertical export diversification.

A depreciating and stable exchange rate has a significant and positive effect at $1 \%$ significance level on vertical and horizontal export diversification in the full sample as well as for SSA's sub-sample; which is in line with the theory indicating a depreciating currency is an appropriate macroeconomic fundamental to support increases in existing exports and ease potential exportable products into new markets. However, this is not always true in the case of East Asia. The empirical analysis from the East Asian sub-sample indicates depreciation was positively associated with vertical export diversification, while horizontal diversification was associated with currency appreciation. Similar results have been recorded by Abeysinghe and Tan Lin (1998) that Singapore's economic growth was associated with continued currency appreciation for the last three decades. Especially, if a country's export inputs are mainly imported as the case of Singapore and Japan, currency appreciation may have more positive effects on economic growth rather than currency depreciation. All in all, however, the empirical results for the full-sample as well as the sub-samples except East Asia's horizontal export diversification confirm the importance of a depreciating and stable exchange rate as one of the key factors to promote export diversification.

Finally, the 'Africa Dummy' which is a proxy to indicate regional differences in export diversification as a result of factors which are not already included in the model has been found to be significant with negative signs. There are at least two interpretations for this result. One interpretation is that there are higher levels of technology spillovers in East Asian countries, mainly because of their geographical proximity to Japan; 
whereas such kind of economic power is absent in the case of SSA. Another explanation could be the cultural factors in East Asian countries that Confucius teachings and philosophies have deep influence in personal and government morality such as justice and sincerity, loyalty, hard workingness, saving, environmental protection, etc. These factors are, however, relatively loose and very low in Africa compared to East Asia and ultimately affecting SSA negatively for its diversification effort.

\section{Concluding remarks and policy implication}

To sum up, most of the empirical results of the variables under consideration are consistent between the full sample and the separate estimations of the two regions. The empirical results from the full sample as well as the sub-samples confirm education, health , income per capita, population size, infrastructural development, openness, arable land ratio, depreciating exchange rate are the most significant and positive determinants to induce vertical as well as horizontal export diversification. Though FDI was found to be a key positive determinant of vertical as well as horizontal export diversification in East Asia, the evidence from SSA however confirms that FDI was significant only in the case of vertical diversification for SSA. Moreover, the elasticity's of those determinants such as human capital and FDI were much higher in East Asia than SSA. This may be explained that East Asian countries have devoted significant amount of investment on education, health, infrastructure and these in turn created a better conducive atmosphere for FDI inflow into those countries. By the same token, the study revealed that domestic investment plays an important role to induce vertical as well as horizontal export diversification in the case of East Asia, while it was significant only for horizontal diversification in SSA. This implies that East Asian countries were also successful in raising domestic savings and creating adequate domestic capital that might have contributed to intensify export diversification.

The study also confirms a country's level of development, population size, quality of infrastructure, and degree of openness are also significant and positive determinants for vertical as well as horizontal export diversification in the analysis of the two sub-samples. Likewise, natural resource wealth especially arable land in which SSA is better endowed has also a positive and significant effect for diversification and this implies that not all types of natural resource endowment have a 'Dutch disease' effect as sometimes generalized by some researchers. However, the oil dummy variable was negatively associated with vertical and horizontal export diversification in SSA and only with vertical diversification in East Asia. Interestingly, oil wealth is positively associated with horizontal export diversification in the case of East Asia. Again, this 
implies that the 'Dutch disease' effects of oil wealth are mostly notable in the case of vertical export diversification rather than horizontal diversification. While inflation, exchange rate, and foreign aid variables have a mixed effect on vertical and horizontal export diversification, political instability was found to be a major key negative factor for vertical as well as horizontal export diversification; especially for SSA. This may prove the hypothesis we set at the outset that in a country with political instability and frequent war, the level of saving as well as investment become very low and this in turn may negatively affects export diversification. Finally, the 'Africa Dummy' which is a proxy to indicate regional differences in export diversification as a result of factors which are not already included in the model has been found to be significant with negative signs. The first reason is perhaps East Asian countries are in advantageous positions to benefit from technology spillovers from Japan due to their geographical proximity. Whereas; such type of economic power is absent in the SSA. Secondly, the cultural factors in most of East Asia are deeply influenced by the Confucius teachings and philosophies that has a wide impact on personal and government morality such as justice and sincerity, loyalty, hard workingness, saving, etc. These factors are, however, relatively loose and very low in Africa compared to East Asia.

The policy implications of this study are relatively straightforward. The lesson from East Asia to SSA is that investment on human capital and physical infrastructure through foreign investment as well as domestic capital formation are key factors, as are stable macro-economic and political environment, a stable and flexible exchange rate, and a fair and an open trading framework are all crucial ingredients to accelerate vertical and horizontal export diversification and ultimately promote structural change on the economy. In line with this, this study recommends SSA countries to follow a dual strategy of vertical and horizontal export diversification, mainly by supporting backward and forward linkages into higher value-added resource-based industries and gradually shift production and exports from customary products to more dynamic ones by developing a competitive advantage in the world market. Although export diversification can't be expected to become a panacea for SSA's deep-rooted economic problems which are a result of three/four decades stagnation, it is however one of the key measures for structural solutions and a prerequisite to achieving a sustained and rapid economic development. 


\section{References}

Abeysinghe, Tilak and Yeok Tan Lin. 1998. Exchange Rate Appreciation and Export Competitiveness: The Case of Singapore. Applied Economics, 30 (1): 51-55.

Abramovitz, Moses.1986. Catching-up, Forging Ahead and Falling Behind. Journal of Economic History, 46(2): 385-406.

Acemoglu, Daron and Fabrizio, Zilibotti. 1997. Was Prometheus Unbound by Chance? Risk, Diversification and Growth. Journal of Political Economy. 105(4): 709-51.

Agosin, Manuel. 2007. Export Diversification and Growth in Emerging Economies. Working Paper, No. 233. Departamento de Economía, Universidad de Chile, Santiago. . 2005. Radical Social Security Reform Is Not Needed: a Letter Commenting on The Economic Agenda by N. Gregory Mankiw. The Economists' Voice, Berkeley Electronic Press, 2(1):2

Ridwan Ali, Jeffrey Alwang and Paul B. Siegel. 1991. Is Export Diversification the Best Way to Achieve Export Growth and Stability? A look at three African Countries. Policy Research Working Papers Series, No 729. World Bank, Washington DC, USA.

Al-Marhubi, Fahim. 2000. Export Diversification and Growth: An Empirical Investigation. Applied Economics Letters 7: 559-62.

Gutierrez de Pineres, Sheila and Ferrantino, Michael. 1997. Export Diversification and Structural Dynamics in the Growth Process: The Case of Chile. Journal of Development Economics, Vol. 52, pp. 35-91. 2000. Export Dynamics and Economic Growth in Latin America. Burlington, Vermont: Ashgate Publishing Ltd.

Amurgo-Pacheco, Alberto and Pierola, Martha. 2008. Patterns of Export Diversification in Developing Countries: Intensive and Extensive margins. Policy Research Working Paper, No.4473. Washington, DC: International Trade Department, World Bank.

Asian Development Bank. 2001. Moving the Poverty Agenda Forward in Asia and the Pacific: The Long-term Strategic Framework of the Asian Development Bank (2001-2015). Asia Development Bank

Athukorala, Premachandra. 1991. An Analysis of Demand and Supply Factors in Agricultural Exports from Developing Asian Countries. Weltwirtschaftliches Archiv, 127, (4), 746-91.

Baltagi, Badi. 1996. Econometric Analysis of Panel Data. Chichester: John Wiley \& Sons Ltd.

Robert J Barro. 1997. Determinants of Economic Growth: A Cross-Country Empirical Study. Cambridge: MIT Press.

Barro, Robert and Sala-i-Martin, Xavier. 1999. Economic Growth. Cambridge, Massachusetts: MIT Press.

Barro, Robert and Lee, Jong-Wha. 2000. International Data on Educational Attainment: Updates and Implications. CID Working Paper, No. 042.

Baumol, William; Nelson, Richard; and Wolf, Edward. 1994. Convergence of Productivity: Cross National Studies and Historical Evidence. New York: Oxford University Press.

Bebczuk, Ricardo and Berrettoni, Daniel. 2006. Explaining Export Diversification: An Empirical Analysis. CAF Research Paper, No. 65. Universidad Nacional de La Plata, Argentina 
Ben Hammouda, H., Karingi; S., Njuguna, A., and Jallab, M. 2006. Diversification: Towards a New Paradigm for Africa's Development. Work in Progress, No. 35. Addis Ababa, African Trade Policy Centre: Economic Commission for Africa.

Bleaney, Michael and Greenaway, David. 2001. The Impact of Terms of Trade and Real Exchange Volatility on Investment and Growth in Sub-Saharan Africa. Journal of Development Economics 65: 491-500.

Bonaglia, Federico and Fukasaku, Kiichiro. 2003. Export Diversification in Low-Income Countries: An International Challenge after Doha. Working Paper No. 209. OECD, Paris.

Bruno, Michael and Easterly, William. 1995. Inflation Crises and Long-run Growth, Journal of Monetary Economics, Vol. 41, pp.3-26.

Canning, David and Bennathan, Esra. 2000. The Social Rate of Return to Infrastructure Investments. Policy Research Working paper, No. 2390. Washington DC, World Bank.

Carrere, Celine; Cadot, Olivier., and Strauss-Khan, Vanessa. 2007. Export Diversification: What's Behind the Hump? CEPR Discussion Paper No. DP 6590

Chenery, Hollis. 1979. Structural Change and Development Policy. New York: Oxford University Press.

Commission for Africa. 2005. Our Common Interest: An Argument. London: Penguin Books Ltd.

Cramer, Christopher. 1999. Can Africa Industrialize by Processing Primary Commodities? The Case of Mozambican Cashew Nuts, World Development, 27 (7): pp.1247-1266.

De Ferranti, D., Perry, G.E., Lederman, D., and Maloney, W. 2002. From Natural Resources to the Knowledge Economy. Washington, DC: The World Bank.

Deininger, Klaus and Squire, Lyn. 1996. A New Data Set Measuring Income Inequality, World Bank Economic Review, Vol. 10, pp. 56591.

Dennis, Allen and Shepherd, Ben. 2007. Trade Costs, Barriers to Entry, and Export Diversification in Developing Countries. World Bank Policy Research Working Paper, No. 4368 , pp. 1-40.

Economic Report on Africa. 2007. Accelerating Africa's Development through Diversification. United Nations Economic Commission for Africa Publication. Sales No. E.07.II.K.1. Addis Ababa.

Elbadawi, Ibrahim. 1999. Can Africa Export Manufactures: The Role of Endowment, Exchange Rates, and Transaction Costs. World Bank policy Research Working Paper, No. 2120. Washington DC. World Bank Economic Development Institute.

Feenstra, Robert \& Hiau Looi Kee. 2004. Export Variety and Country productivity. Policy Research Working Paper Series 3412, The World Bank.

Gerber, James. 2005. International Economics ( $3^{\text {rd }}$ ed.). Boston, MA: Addison-Wesley.

Ghosh, Atish and Ostry, Jonathan. 1994. Export Instability and the External Balance in Developing Countries. IMF Staff Papers 41: 214-35.

Grossman, Gene and Helpman, Elhanan. 1991. Innovation and Growth in the Global Economy. Cambridge, MA: MIT Press.

Gujarati, Damodar. 2003. Basic Econometrics. Fourth edition, Singapore: McGraw-Hill Companies, Inc. 
Glyfason, Thorvaldur. 2001. Natural Resources, Education, and Economic Development. European Economic Review 45 (4-6): 847-59. 2002. Institutions, Human Capital, and Diversification of Rentier Economies, University of Iceland, CEPR, and CESifo. . 2004. Natural Resources and Economic Growth: from Dependence to Diversification, CEBR Discussion Paper, No. 4804.

Habiyaremye, Alexis and Ziesemer, Thomas. 2006. Absorptive Capacity and Export Diversification in Sub-Saharan African Countries. Maastrich: United Nations University.

Hausmann, Ricardo and Rodrik, Dani. 2003. Economic Development as Self-Discovery. Journal of Development Economics 72: 603-33.

Hausmann, Ricardo and Klinger, Bailey. 2006. Structural Transformation and Patterns of Comparative Advantage in the Product Space. Working Paper No. 128. Center for International Development, Harvard University.

2007. The Structure of the Product Space and the Evolution of Comparative Advantage. CID Working Paper, No. 146, Center of International Development: Harvard University.

Hausmann, Ricardo; Hwang, Jason., and Rodrik, Dani. 2006. What You Export Matters. Working Paper. Center for International Development, Harvard University.

Herzer, Dierk and Nowak-Lehmann, Felicitas. 2006. What Does Export Diversification Do for Growth? An Econometric Analysis, Journal of Applied Economics, Volume 38, pp 1825-1838.

Herzer, Dierk; Nowak-Lehmann, Felicitas and Siliverstovs, Borris. 2004. Export-led Growth in Chile: Assessing the Role of Export Composition in Productivity Growth. Discussion Paper 103. Ibero America Institute for Economic Research (IAI).

Hirschman, Albert. 1958. The Strategy of Economic Development. New Haven, CT: Yale University Press.

Husted, Steven and Melvin, Michael. 2007. International Economics. New Jersey: Pearson Education, Inc.

Imbs, Jean and Wacziarg, Romain. 2003. Stages of Diversification. American Economic Review 93(1): 63-86.

Janneh, Abdoulie. 2009. Afrol News, 5th World Business Congress and the 1st IGAD Investment Forum in Addis Ababa, March 3rd 2009.

Kwan, C. H. 1998. The Yen, the Yuan, and the Asian Currency Crisis: Changing Fortune between Japan and China. Occasional Papers, Stanford University: Asia/Pacific Research Center, Institute for International Studies.

Labys, Walter and Montague J. Lord. 1990. Portfolio Optimization and the Design of Latin American Export Diversification Policies. Journal of Development Studies. 26 (2) 260-77.

Lall, Sanjaya. 1992. Technological Capabilities and Industrialization, World Development Report, Vol.20, pp. 165-186.

Lederman, Daniel and Maloney, William. 2007. Trade Structure and Growth. In Natural Resources: Neither Curse nor Destiny, D. Lederman and W.F. Maloney, eds. Palo Alto: Stanford University Press.

Love, James. 1983. Concentration, Diversification and Earnings Instability: Some Evidence on Developing Countries' Exports of Manufactures and primary products.) In World Development, Vol.11, No.9:787-793. 
Maizels, Alfred. 1987. Commodities in Crisis: An Overview of the Main Issues. World Development, Vol. 15, No. 5: 537-49.

Mankiw, N. G. 2003. Macroeconomics. New York: Worth Publishers.

Matsuyama, Kiminori. 1992. Agricultural Productivity, Comparative Advantage, and Economic Growth. Journal of Economic Theory 58: 317-34.

Masuyama, Seiichi and Vandenbrink, Donna. 2001. Industrial Restructuring in East Asian Economies for the Twenty-first Centuries. Tokyo: Tokyo Club foundation for Global Studies.

Mkandawire, Thandika and Soludo, Charles. 1999. Our Continent, Our Future: African Perspectives on Structural Adjustment. Council for the Development of Social Science Research in Africa: Africa World Press, Inc.

Munemo, J., Bandyopadhyay, S., and Basistha, A. 2007. Foreign Aid and Export Performance: A Panel Data Analysis of Developing Countries. Working Paper 2007-023A, St. Louis: Federal Reserve Bank of St. Louis.

Nelson, Richard and Phelps, Edmond. 1966. Investment in Humans, Technological Diffusion, and Economic Growth, American Economic Review Proceedings, LVI: 69-75.

$\mathrm{Ng}$, Francis and Yeats, Alexander. 2002. What Can Africa Expects from its Traditional Exports? Africa Region Working Paper Series, No.26, Washington DC, The World Bank.

Obstfeld, Maurice. 1994. Evaluating Risky Consumption Paths: The Role of Inter-temporal Substitutability. European Economic Review, 38 (7): 1471-1486.

Olofsdotter, Karin. 1998. Foreign Direct Investment, Country Capabilities and Economic Growth, Weltwirtschaftliches Archive, 134 (3): 534-547.

Osakwe, Patrick. 2007. Foreign Aid, Resources, and Export Diversification in Africa: A New Test of Existing Theories. African Trade Policy Paper, No. 61, Addis Ababa: Economic Commission for Africa

Owens, T. and Wood, A. 1997. Export-Oriented Industrialization through Primary Processing? World Development, 25, (9): 1435-1470.

Parteka, Alexsandra and Tamberi, Massimi. 2008. Determinants of Export Diversification: An Empirical Investigation, Working Papers, Universita Politecnica Delle Marche, Italy, No. 327, pp.1-45.

Pinaud, Nicolas. and Wegner, Lucia. 2004. African Economic Performance in 2004: A Promise of Things to Come? Policy Insights, No.6: OECD.

Roskamp, Karl and McMeekin, Gordon. 1968. Factor Proportions, Human Capital and Foreign Trade: The Case of West Germany Reconsidered, Quarterly Journal of Economics, Vol. 82, pp. 52-60.

Sachs, J., Mc Arthur, J., SchmidtTraub, G., Kruc, M., Bahadur, C., Faye, M. and McCord, G. 2004. Ending Africa's Poverty Traps, Brookings Papers in Economics.

1997. Natural Resource Abundance and Economic Growth, Centre for International Development and Harvard Institute for International Development: Harvard University, Cambridge, USA.

2001. The Curse of Natural Resources. European Economic Review, Elsevier, vol. 45(4-6): 827-838.

Saint-Paul, Gilles. 1992. Technological Choice, Financial Markets, and Economic Development, European Economic Review, 36 (4): pp. 763-781. 
Sandee, Henry and Wengel, Jan ter. 2004. SMEs in Southeast Asia since the Asian Financial Crisis. In Entrepreneurship and SMEs in Southeast Asia, edited by Denis Hew and Loi Wee Nee. Singapore: Seng Lee Press Ltd.

Ssemogerere, Geremina and Kasekende, L. A. 1994. Constraints to the Development and Diversification of Non-traditional Exports in Uganda (1981-90). African Economic Research Consortium Research Paper 28, Nairobi.

Stiglitz, Joseph. 2006. Aid for Trade, Paper Prepared for the Annual World Bank Conference on Development Economics, Tokyo, Japan; May 29-30, 2006.

Syrquin, Moshe. 1988. Patterns of Structural Change. In H. Chenery and T.N. Srinivasan (eds.) Hand Book of Development Economics, Volume. 1, PP 203-273. New York, NY: Elsevier.

Taylor, lan. 2006. China's Oil Diplomacy in Africa, International Affairs, Volume 82, No. 5: 937-959.

Thomas, Vinod and Wang, Yan. 1997. Government Policies and Productivity Growth: Is East Asia an Exception? In Lessons from East Asia, edited by Leipziger, D. and Thomas, V. Ann Arbor, USA: The University of Michigan Press, 1997, pp. 483-509.

UNCTAD. 2003. Economic Development in Africa: Trade Performance and Commodity Dependence. New York and Geneva: United Nations. 2008a. Economic Development in Africa. United Nations Publication, Sales, No. E. 08. II. D22. New York and Geneva: United Nations. 2008. UNCTAD Handbook of Statistics. New York and Geneva: United Nations.

Van Wijnbergen, Sweder. 1985. Aid, Export Promotion and the Real Exchange Rate: An African Dilemma, CEPR Discussion Paper No. 88. London: Centre for Economic Policy Research.

Vernon, Raymond. 1966. International Investment and International Trade in the Product Cycle, Quarterly Journal of Economics, Vol. 80, pp. 190-207.

Wheeler, David and Mody, Ashoka. 1992, International Investment Location Decisions: The Case of U.S. Firms, Journal of International Economics, Vol. 33, Issue 1-2, pp. 57-76.

Wood, Andrian and Mayer, Jorg. 1998. Africa's Export Structure in a Comparative Perspective, Cambridge Journal of Economics, Vol. 25, No. 3: 369-394.

Wooldridge, Jeffrey. 2002. Econometrics Analysis of Cross Section and Panel Data. Massachusetts: MIT Press.

World Bank. 2002. From Natural Resources to the Knowledge Economy: Trade and Job Quality. Latin American and Caribbean Studies. Washington, DC: World Bank. .1999. World Development Report Summary 1998-99: Knowledge for Development. Washington, DC. World Bank. .

1993. The East Asian Miracle: Economic Growth and Public Policy. New York: Oxford University Press. 2008a. World Development Indicators. Online database.

World Trade Organization. 2001. International Trade Statistics. Geneva: World Trade Organization. 